\title{
Openness in International Adoption
}

Malinda L. Seymore

Texas A\&M University School of Law, mseymore@law.tamu.edu

Follow this and additional works at: https://scholarship.law.tamu.edu/facscholar

Part of the Family Law Commons, and the International Law Commons

\section{Recommended Citation}

Malinda L. Seymore, Openness in International Adoption, 46 Colum. Hum. Rts. L. Rev. 163 (2015).

Available at: https://scholarship.law.tamu.edu/facscholar/707

This Article is brought to you for free and open access by Texas A\&M Law Scholarship. It has been accepted for inclusion in Faculty Scholarship by an authorized administrator of Texas A\&M Law Scholarship. For more information, please contact aretteen@law.tamu.edu. 


\title{
OPENNESS IN INTERNATIONAL ADOPTION
}

\author{
Malinda L. Seymore*
}

\begin{abstract}
After a long history of secrecy in domestic adoption in the United States, there is a robust trend toward openness. That is, however, not the case with international adoption. The recent growth in international adoption has been spurred, at least in part, by the desire of adoptive parents to return to closed, confidential adoptions where the identity of the birth mother is secret and there is no ongoing contact with her. There is, however, an emergent interest in increased openness in international adoption, spurred by the success of domestic open adoptions, health concerns when an adoptee's genetic history is important, psychological issues relating to identity in adoptees, and concern that the international adoption might have been corrupt. International adoptive families who were once happy to avoid birth parent involvement have begun to seek them out.

Increased openness in international adoption is mandated by international human rights and, in particular, the U.N. Convention on the Rights of the Child and the Hague Convention on Protection of Children and Co-Operation in Respect of Intercountry Adoption. In addition, a growing body of research demonstrates that open adoptions are in the best interests of children as they grow and develop a sense of identity. The transparency of open adoption can also serve to ameliorate fraud and corruption in adoption. Therefore, countries involved in international adoption, and the international human rights community, need to take adopted children's right to identity seriously.
\end{abstract}

* Professor of Law, Texas A \& M University School of Law. I gratefully acknowledge the financial and institutional support of Texas A \& M, without which this Article would have languished, unfinished, for years. I am grateful for the unflagging support of my faculty colleagues and their lively engagement when I presented this topic. A special acknowledgement is owed to Megan Carpenter for setting me on the right path, Tanya Pierce for keeping me there, and Patrick Flanagan for finding the most obscure resources along the way. As is the tradition among those who write about adoption, I wish to note my place in the adoption triad: I am an adoptive parent of two daughters from China. I dedicate this Article to them and to their unknown birth parents. 


\section{INTRODUCTION}

[S]ecrecy is the foundation underlying all adoptions and if this secrecy is not to continue this great work must suffer. ${ }^{1}$

I believe that the only thing unusual about my papers is that I have them. The only reason I was able to get the Korean papers is because I had permission from my Korean family. So you see the dilemma-if the agencies require permission from the birth family to get the papers, how are most adoptees or adoptive families ever going to see the papers if they haven't located the birth family in the first place? ${ }^{2}$

In all of us there is a hunger, marrow-deep, to know our heritage - to know who we are and where we have come from. Without this enriching knowledge, there is a hollow yearning. No matter what our attainments in life, there is still a vacuum, an emptiness-, and the most disquieting loneliness. ${ }^{3}$

After a long history of secrecy in domestic adoption in the United States, there is a robust trend toward openness. Oftentimes, the birth mother and adoptive parents have met prior to the child's placement for adoption. Open adoption, defined as various forms of continuing contact between birth families and adoptive families after an adoption is finalized, is growing. States are slowly opening adoption records to adult adoptees, including allowing access to original birth certificates showing the names of birth parents. Birth parent-adult adopted child reunions are happening every day in America. This is not to say that America has reached an adequate level of openness in adoption, but that the current trend is toward ever-increasing openness. ${ }^{4}$

1. E. Wayne Carp, Family Matters: Secrecy and Disclosure in the History of Adoption 106 (2000) (quoting the New York court in rejecting a birth mother's plea for information on the whereabouts of the son she placed for adoption) [hereinafter Carp, Family Matters].

2. Jane Jeong Trenka, My Adoption File, Jane's Blog: Bitter Angry Ajumma (last updated June 16, 2014), http://jitrenka.wordpress.com/about/adoption-file.

3. Alex Haley, What Roots Means to Me, Reader's Digest, May 1977, at 73.

4. Susan M. Wolfgram, Openness in Adoption: What We Know So Far - A Critical Review of the Literature, 53 Social Work 133, 136 (2008) ("The term open 
The move toward openness is much newer and progressing much slower in international adoption. In fact, many American adoptive parents are drawn to international adoption because there is little birth parent involvement. ${ }^{5}$ Many intercountry adoptees are long separated from their birth families before any adoption takes place, limiting pre-adoption contact between birth parents and adoptive parents. ${ }^{6}$ Contact at the time of adoption is equally rare. ${ }^{7}$ Poverty, lack of education, and the political powerlessness of the birth parents, as well as the vast distances that usually separate the birth country and adoptive country make continuing contact difficult, if not impossible. ${ }^{8}$ Language barriers, cultural differences, and

adoption refers to a continuum of options that enables birth parents and adoptive parents to have information about and communication with one another before or after placement of the child or at both times."). Deborah H. Siegel \& Susan Livingston Smith, Evan B. Donaldson Adoption Institute, Openness in Adoption: From Secrecy and Stigma to Knowledge and Connections 10 (2012). The continuing contact in open adoption can vary from mediated exchange of information and photos throughout the child's life to continuing in-person contact between the birth family, the adoptive family, and the child. Id. at 12 .

5. Karen Sotiropoulos, Open Adoption and the Politics of Transnational Feminist Human Rights, 101 Radical History Rev. 179, 185 (2008) (noting the link between the rise in open adoption in the U.S. and in international adoption: "the explanation offered by more than a few adoptive parents who explain their choice to adopt internationally as rooted in their desire to avoid birthmothers"). See also Hosu Kim, Mothers Without Mothering: Birth Mothers from South Korea Since the Korean War, in International Korean Adoption: A Fifty-Year History of Policy and Practice 131, 142 (Kathleen Ja Sook Bergquist, et al., eds., 2007) (noting that the presence of the birth mother is "discomfiting" for adoptive parents, motivating transnational adoptions, which are "closed transactions").

6. I use "international" and "intercountry" interchangeably in the context of cross-border adoption. International adoption is the more common term, but since the Hague Convention uses intercountry adoption, that descriptor has entered the vernacular.

7. David M. Smolin, Intercountry Adoption and Poverty: A Human Rights Analysis, 36 Cap. U.L. Rev. 413, 416 (2007) (noting that the international adoption system "usually keeps adoptive parents and birth families separated from one another"). See also Jacqueline Bhabha, Moving Babies: Globalization, Markets and Transnational Adoption, 28 Fletcher F. World Aff. 181, 186 (2004) (arguing that "anonymity is essential for the success of the adoptive transaction," since the "effective invisibility of birth parents fuels the fiction of consent").

8. Alison Fleisher, The Decline of Domestic Adoption: Intercountry Adoption as a Response to Local Adoption Laws and Proposals to Foster Domestic Adoption, 13 S. Cal. Rev. L. \& Women's Stud. 171, 191 (2003); Jini L. Roby \& Stephanie Matsumura, If I Give You My Child, Aren't We Family? A Study of Birthmothers Participating in Marshall Islands-U.S. Adoptions, 5 Adoption Quarterly 7, 25 (2002) (noting that the lack of international law and birth family resources would "deprive them of recourse to challenge" adoptions). 
the impenetrability of foreign legal systems hamper efforts of adult adoptees to get information about birth families. ${ }^{9}$ In some instances, information about birth families does not exist in any in-country file, ${ }^{10}$ and in other instances, information is falsified. ${ }^{11}$

There is, however, a growing interest in increased openness in international adoption. International adoptive families who were once happy to avoid birth parent involvement are now seeking them out because of health concerns ${ }^{12}$ or because their child is interested in learning about their birth parents. ${ }^{13}$ Some adoptive families are concerned about issues of corruption, coercion, and trafficking in the

9. Fleisher, supra note 8, at 190-91.

10. See Harold Grotevant, et al., Adoptive Identity: How Contexts Within and Beyond the Family Shape Developmental Pathways, 49 Family Relations 379, 380 (2000) ("Children adopted from countries outside the U.S. typically have little or no information about their birthparents. For some children, information about the orphanage from which they came might be available, but information about their birthparents might never be.").

11. Trenka, supra note 2 (discussing the inaccuracies in the author's adoption file relating to information about her birth parents and other matters). See also Kathryn Joyce, The Child Catchers: Rescue, Trafficking, and the New Gospel of Adoption 131, 142, 157, 159, 175, 181 (2013) (discussing various falsehoods in the files of children adopted from Ethiopia, including lies about the age of the children, falsehoods about siblings, and even falsehoods claiming the death of parents who were still alive); In the Matter of Cha Jung Hee (Mu Films 2010)(a film by Deann Borshay Liem) (documenting the search of an eight-yearold Korean girl, who was adopted under the name Cha Jung Hee, for her birth mother who was still alive).

12. The need of international adoptees to find their birth family because of essential medical treatment has been frequently reported. See, e.g., Cheryl Powell, Leukemia Fight Breaks Barriers of Culture, Miles, Akron Beacon Journal, (Nov. 30, 2008), http://www.ohio.com/news/leukemia-fight-breaks-barriers-of-culturemiles-1.160051; Girl With Leukemia Searches for Birth Family, Beijing Today (Oct. 17, 2008), http://english.qianlong.com/article.jsp?oid=44996951\&pageno=1; Ryan Sabalow, Deena Back in School: Redding Child Does Well After Bone Marrow Transplant, Redding Record Searchlight (May 1, 2007), http://www.redding.com/news/deena-back-in-school (family flies in birth mother from Thailand for bone marrow transplant); Donor found for China adoptee Kailee Wells, Kailee Get Wells, http://www.kaileegetwells.com/update.htm\#bigbignews (last visited Mar. 23, 2015); Thomas Fields-Mayer, For a Native Son, People Magazine (Mar. 4, 1996), http://www.people.com/people/archive/article/ 0,20102939,00.html (describing the search for a South Korean adoptee's birth family in order to find a bone marrow match for a transplant as "like looking for a needle in a haystack ... . Except you don't know for sure there even is a needle.").

13. Skila Brown, Birth Parent Search in International Adoption, Adoptive Families (2013), http://www.adoptivefamilies.com/articles.php?aid=1756. Video available at http://player.omroep.nl/?aflID=3906136\&md5= 5fd831a8f38a0a5db3f5b1cd0f06b7e9 (English translation on file with the author). 
birth country and want contact with birth parents to assuage those concerns. ${ }^{14}$ International adoptive families are learning about positive outcomes of domestic open adoptions and hope to replicate those results in the international context. ${ }^{15}$ International adoptees are reaching adulthood and are increasingly interested in searching for birth families, despite the many practical difficulties in doing so. ${ }^{16}$

There is much discussion among child welfare specialists, adoption advocates, and scholars about international adoption and human rights. That discussion is primarily about whether international adoption should exist. However, there is little discussion about what international adoption should look like as it exists. The primary purpose of international human rights instruments concerning adoption "has been to regulate the process of adoption to ensure procedural justice and reliable fairness in the protocols surrounding adoption."17 There is little in these conventions addressing what adoption should look like once the initial match is made. This Article will examine whether human rights compels a particular form of adoption-open adoption.

This Article will consider the legal framework for openness in international adoption by comparing it with the legal framework for openness in domestic adoption in the United States and by assessing arguments about the application of international human rights law, including the U.N. Convention on the Rights of the Child ${ }^{18}$ and the

14. Carrie Howard, Searching for Birth Families, Adoptive Families (2013), http://www.adoptivefamilies.com/articles.php?aid=1562; Elizabeth Larson, Did I Steal My Daughter?, Mother Jones Magazine (Nov./Dec. 2007), http://www.motherjones.com/politics/2007/10/did-i-steal-my-daughter-tribulationsglobal-adoption.

15. See discussion of domestic open adoption, infra, at text accompanying notes 88-118. See also Larson, supra note 14 (noting that international adoptive families are motivated to search because of the success of open adoption domestically).

16. Several international adoptees have written memoirs about their search for birth parents. See e.g., Katy Robinson, A Single Square Picture: A Korean Adoptee's Search for Her Roots (2002); Mei-Ling Hopgood, Lucky Girl (2010); Jane Jeong Trenka, The Language of Blood: A Memoir (2005); Jane Jeong Trenka, Fugitive Visions: An Adoptee's Return to Korea (2009); Asha Miro, Daughter of the Ganges: The Story of One Girl's Adoption and Her Return Journey to India (2007).

17. Marie A. Failinger, Moving Toward Human Rights Principles for Intercountry Adoption, 39 N.C.J. Int'l L. \& Com. Reg. 523, 526 (2014).

18. Convention on the Rights of the Child, Nov. 20, 1989, 1577 U.N.T.S. 3. [hereinafter CRC]. Although the United States has not ratified the CRC, virtually every other receiving country and sending country in international adoption has ratified it. Thus, it is clearly relevant here. 
Hague Convention on Protection of Children and Co-Operation in Respect of Intercountry Adoption..$^{19}$ Part I of this Article sets out the history of secrecy and openness in domestic adoption in the United States and examines the psychological and sociological research supportive of open adoptions and open access to adoption records. Part II examines international law and makes an argument that openness in international adoption is compelled by the existing legal framework of international human rights law. In particular, international human rights conventions guarantee rights of identity and information that require increased openness in international adoption. In addition, best interests of the child standards in international law point to a need for the same kinds of open adoption arrangements which have been studied in the West and have been determined to benefit children. Further, openness in international adoption is a practical solution to fraud, corruption, and trafficking in international adoption by using the "sunlight as disinfectant" method. In Part III, I offer suggestions to facilitate increased openness in international adoption. Part IV contains brief concluding remarks.

\section{OPENNESS IN DOMESTIC ADOPTION IN THE UNITED STATES}

\section{A. History of Secrecy}

The passage of the Massachusetts Adoption Act of 1851 is considered the beginning of modern adoption law and practice in America. ${ }^{20}$ Before that point-and for a time after-adoption occurred informally and in such a way that it was functionally open. ${ }^{21}$ Children were adopted at an older age and likely knew the identity and whereabouts of their birth parents. ${ }^{22}$ Adoptions were arranged

19. Hague Convention on Protection of Children and Co-operation in Respect of Intercountry Adoption, May 29, 1993, 32 I.L.M. 1134 [hereinafter Hague Convention].

20. Stephen B. Presser, The Historical Background of the American Law of Adoption, 11 J. Fam. L. 443, 460-61 (1972); Katarina Wegar, Adoption, Identity, and Kinship: The Debate Over Sealed Birth Records 3-4 (1997); Carp, Family Matters, supra note 1, at 11; Naomi Cahn, Perfect Substitute or the Real Thing?, 52 Duke L.J. 1077, 1102-04 (2003).

21. Siegel \& Livingston, supra note 4 , at 10 ; Wolfgram, supra note 4 , at 133.

22. Carp, Family Matters, supra note 1, at 73, 88 (1998) (before World War II, a high proportion of adopted children were "older children," between four and six years old, and confidentiality would not work "since all parties had so much knowledge of the situation."); Barbara Melosh, Strangers and Kin: The American Way of Adoption 223 (2002). 
between the biological and adoptive parents, so each knew the identity and whereabouts of the other. ${ }^{23}$ Newborn adoption, with an adoption agency as an intermediary between parents, did not exist until much later. ${ }^{24}$

While secrecy was not enforced against adoptees and adoptive parents, it became the norm to invoke secrecy against birth parents-at least as to the location of their placed-out children. Social reformers placing out children-such as the infamous Charles Loring Brace and the "Orphan Trains" Project ${ }^{25}$-felt that birth parents should never know the names of the adoptive parents or the location of their children. ${ }^{26}$ These reformers were concerned that all of their good work in "saving" the children would be undone if birth parents could locate the children and reunite with them. ${ }^{27}$ Progressive Era social workers began to include in the relinquishment forms signed by birth parents promises not to seek

23. See Carp, Family Matters, supra note 1, at 197 (describing that the Home Missionary Society of Philadelphia directed parents and potential adoptive parents to make their own agreements); see also Siegel \& Livingston, supra note 4 , at 10 (stating that many adoptions have historically taken place informally within extended families).

24. See Sotiropoulos, supra note 5, at 182 (noting the rarity of infant adoption before World War II); see also Ellen Herman, Kinship by Design: A History of Adoption in the Modern United States 143-44 (2008) (discussing the changes agencies began to make after World War II to compete with independent private adoption, including placing newborns, a practice once thought dangerous because such a young child's potential hereditary faults were not yet identifiable).

25. Claudia Nelson, Little Strangers: Portrayals of Adoption and Foster Care in America, 1850-1929 10-11 (2003) (noting that the Boston Children's Misson's George Merrell should rightfully be credited with the beginning of the orphan trains, with Charles Loring Brace "considered its chief publicist").

26. Carp, Family Matters, supra note 1, at 103; Stephen O'Connor, Orphan Trains: The Story of Charles Loring Brace and the Children He Saved and Failed (2004); Marilyn Irvin Holt, Adoption Reform, Orphan Trains, and Child Saving, 1851-1929, in Children and Youth in Adoption, Orphanages, and Foster Care: A Historical Handbook and Guide 17, 25 (Lori Askeland ed., 2006) (describing how agencies often felt it best to cut all ties between children and biological relatives); Rebecca S. Trammell, Orphan Train Myths and Legal Reality, 5 Mod. Am. 3, 5 (2009).

27. Carp, Family Matters, supra note 1, at 103; see also Naomi Cahn, Birthing Relationships, 17 Wis. Women's L.J. 163, 173 (2006) (describing a general attitude of fear that relations between birth mother and adopted child might remain); see also Elizabeth J. Samuels, Surrender and Subordination: Birth Mothers and Adoption Law Reform, 20 Mich. J. Gender \& L. 32, 53 (2013) (stating that records were sealed to protect adoptive families and adoptees from public scrutiny and interference from the birth family) Thereinafter Samuels, Surrender and Subordination]. 
out the child, to learn the child's location, or to interfere in any way with the child or adoptive parents. ${ }^{28}$ By this era, the concern was not only that birth parents seeking their children would "ruin" them, but also that prospective adoptive parents would be dissuaded from adopting for fear that birth parents would reappear in the child's life and steal their affections from the adoptive family. ${ }^{29}$ By 1938 , the Child Welfare League of America included in its "Minimum Safeguards in Adoption" the requirement that "the identity of the adopting parents should be kept from the natural parents. ${ }^{\text {"30 }}$

This mandate of secrecy did not immediately apply to adoption records. For nearly a century after the passage of the Massachusetts Act, adoption records were open and available to birth parents, adopted children, and adoptive parents." "In the mid-1920s, there were virtually no confidentiality or secrecy provisions in adoption law." ${ }^{32}$ Even when the first law addressing confidentiality of adoption records was passed, the Minnesota Children's Act of 1917, ${ }^{33}$ the act was explicit in stating that adoption records would be open to members of the adoption triad, though closed to the public. ${ }^{34}$

While there were more state laws requiring confidentiality by the mid-1930s to the early $1940 \mathrm{~s}$, few laws provided for secrecy among the participants to the adoption, including the birth

28. E. Wayne Carp, Adoption Politics: Bastard Nation \& Ballot Initiative 58 (2004) Thereinafter Carp, Adoption Politics]; Carp, supra note 1, at 104; see also Samuels, supra note 27, at 53-54.

29. Carp, Family Matters, supra note 1, at 105; Janine M. Baer, Growing in the Dark: Adoption Secrecy and Its Consequences 72 (2004); Samuels, Surrender and Subordination, supra note 27, at 53-54 (stating that records were sealed to protect adoptive families from interference by birth families).

30. Baer, supra note 29, at 72 (noting that the CWLA's concern was obviously protecting adoptive parents from interference by birth mothers, not protecting birth mother privacy. It wasn't until 20 years later that the CWLA amended the standard to say that adoptive parents also should not know the identity of birth parents).

31. Carp, Adoption Politics, supra note 28, at 6; Siegel \& Livingston, supra note 4, at 10; Elizabeth J. Samuels, The Idea of Adoption: An Inquiry into the History of Adult Adoptee Access to Birth Records, 53 Rutgers L. Rev. 367, 373-74 (2001) [hereinafter Samuels, The Idea of Adoption]; Ellen Waldman, Wells Conference on Adoption Law: What Do We Tell the Children?, 35 Cap. U.L. Rev. 517, 521-22 (2006).

32. Samuels, The Idea of Adoption, supra note 31, at 374-75.

33. Wegar, supra note 20, at 4.

34. Naomi Cahn \& Jana Singer, Adoption, Identity, and the Constitution: The Case for Opening Closed Records, 2 U. Pa. J. Const. L. 150, 155 (1999); Samuels, The Idea of Adoption, supra note 31, at 373-77. 
parents, adoptive parents, and adoptees. ${ }^{35} \mathrm{~A}$ further step toward confidentiality occurred during this period-states began the practice of providing "amended birth certificates" to those who were adopted. ${ }^{36}$ The amended certificate would list the names of the adoptive parents as the biological parents of the child and would make no mention of birth parents or of adoption. ${ }^{37}$ However, the original birth certificate of the child containing the names of the birth parents was not sealed from disclosure to adoptive parents or the adoptee. ${ }^{38}$

The early justifications for closing records to the public rested on the "stigma of shame and scandal that surrounded adoption and illegitimacy...." ${ }^{39}$ The purpose of confidentiality was to prevent access to records by potential blackmailers or nosy neighbors, not by birth parents, adoptive parents, or adoptees. ${ }^{40}$ This idea of confidentiality was not intended as a way to keep secrets between the parties to the adoption. Many adoption agencies in the period before World War II were very open in providing information to adult adoptees about their birth families. ${ }^{41}$ Disclosure of information-to birth parents, adoptive parents, and adoptees-was the norm for

35. Samuels, The Idea of Adoption, supra note 31, at 374-75; Herman, supra note 24, at 64; D. Marianne Brower Blair, The Impact of Family Paradigms, Domestic Constitutions, and International Conventions on Disclosure of an Adopted Person's Identities and Heritage: A Comparative Examination, 22 Mich. J. Int'l L. 587, 592 (2001).

36. Samuels, The Idea of Adoption, supra note 31, at 375-76; Blair, supra note 35, at 593; see also Melosh, supra note 22, at 1-2 (describing the amended birth certificate of the author's son, who was born in 1985).

37. Samuels, The Idea of Adoption, supra note 31, at 376; Melosh, supra note 22 , at $1-2$.

38. Samuels, The Idea of Adoption, supra note 31, at 376.

39. Carp, Adoption Politics, supra note 28, at 6. See also Samuels, The Idea of Adoption, supra note 31, at 387 (noting that Progressive Era reformers were concerned about "the stigma of the children's illegitimacy...."); Brett S. Silverman, The Winds of Change in Adoption Law: Should Adoptees Have Access to Adoption Records?, 39 Fam. Court Rev. 85, 87 (2001); Burton Z. Sokoloff, Antecedents of American Adoption, 3 The Future of Children 17, 22 (1993).

40. Carp, Adoption Politics, supra note 28, at 6; Samuels, The Idea of Adoption, supra note 31, at 369 (noting that adult adoptees still had unrestricted access to their original records as late as the $1960 \mathrm{~s}$ in $40 \%$ of states). See also Herman, supra note 24, at 64 (explaining that confidentiality was intended to block "curious and unscrupulous persons," not "parties in interest" in the adoption).

41. Carp, Family Matters, supra note 1, at 73; Carp, Adoption Politics, supra note 28, at 7; Sally Sales, Contested Attachments: Rethinking Adoptive Kinship in the Era of Open Adoption, Child and Family Social Work 1 (2013) (noting the break between Pre-World War II and Post-World War II practices about telling in adoption). 
professional social workers who ensured that adoptive parents told their children about their adoptions. ${ }^{42}$ Professional social workers took the position that "the information belonged to adoptees and adoptive parents by right and that it was the social workers' responsibility to collect and provide it when asked." ${ }^{33}$ Thus, until World War II, adoptees, adoptive parents, and birth parents were the beneficiaries of a consensus among legislators, policy makers, and social workers that best practices in adoption included "openness in disclosing information to those most intimately connected to adoption." ${ }^{\prime 4}$

Demographic changes in who placed children for adoption and increased professionalism of social work after World War II led to increased secrecy, even among members of the adoption triad..$^{45}$ Prior to the war, the majority of placing parents were married or divorced, and they relinquished children they were unable to support financially. ${ }^{46}$ After the war, the vast majority of placing parents were younger and unmarried, with a child born out of wedlock who was relinquished within days of birth. ${ }^{47}$ Told that this unwed birth would bring lasting stigma to the mother and child, many birth mothers appreciated the new secrecy of the adoption process. ${ }^{48}$

Social workers, who once firmly embraced disclosure, began to embrace the psychoanalytic theories of Sigmund Freud and others. ${ }^{49}$

42. Carp, Family Matters, supra note 1, at 87; Herman, supra note 24, at 61-64, 270-83.

43. Carp, Family Matters, supra note 1, at 100.

44. Id.; Cahn \& Singer, supra note 34, at 156. See also Samuels, The Idea of Adoption, supra note 31, at 373-77 (describing how, before World War II, adoption records were open to those involved in the adoption); Herman, supra note 24, at 64 (observing that the "original architects of confidential adoption" believed that adoptees "had every legal and moral right to recover whatever facts they wished in adulthood ....").

45. Wolfgram, supra note 4, at 133; E. Wayne Carp \& Anna Leon-Guerrero, When in Doubt, Count: World War II as a Watershed in the History of Adoption, in Adoption in America: Historical Perspectives 181, 183-93 (E. Wayne Carp ed., 2002) (offering an in-depth analysis of demographic characteristics of birth parents relinquishing children before WWII and after WWII); Herman, supra note 24, at 123 ("During the post-World War II era, confidentiality was overtaken by secrecy ....").

46. Carp \& Leon-Guerrero, supra note 45, at 183-93.

47. Carp, Family Matters, supra note 1, at 110; Carp \& Leon-Guerrero, supra note 45, at 183-93 (providing in-depth analysis of demographic characteristics of birth parents relinquishing children before and after WWII).

48. See Carp, Family Matters, supra note 1, at 110-11; Cahn \& Singer, supra note 34 , at 155 .

49. Herman, supra note 24 , at 257. 
Social workers began to view unwed mothers through a lens of psychopathology, describing them as infantile, neurotic, living out adolescent fantasies, having "serious personality disturbances," and needing help with emotional problems ${ }^{50}$ As a result, social workers began to limit contact and information between such birth mothers and their children. ${ }^{51}$ Social worker attitudes toward adult adoptees who sought information about their birth family also underwent a change because of the embrace of psychoanalytic theory-now describing such searchers as "very disturbed" and "sick youths," suffering from Freud's family romance fantasy. ${ }^{52}$ Social workers came to believe that providing information to adult adoptees about their biological parents was therapeutically contraindicated. ${ }^{53}$

The law soon followed these changes in policy-by 1948 a majority of states had enacted legislation that sealed court records of adoption. ${ }^{54}$ By 1960 , twenty-nine states had sealed original birth certificates, even to adoptee access. ${ }^{55}$ By the mid-1960s, the confidentiality regime had transformed into a secrecy regime, with birth parents denied information about the adoptive parents and the child's whereabouts, with adoption records sealed to all, and with records of original birth certificates also sealed. ${ }^{56}$

Since the 1960s, active reform movements driven by adult adoptees have sought to re-open records of adoption and original birth certificates. ${ }^{57}$ One such organization, the Adoptees Liberty Movement

50. Carp, Family Matters, supra note 1, at 114-15; see also Herman, supra note 24, at 88 (discussing how embrace of psychoanalytic theory "professionalized" social workers).

51. See Carp, Family Matters, supra note 1, at 116-17; Cahn \& Singer, supra note 34 , at 157 (discussing the belief that separating mother and child quickly and permanently was necessary for the mother's recovery from her emotional problems).

52. Carp, Family Matters, supra note 1, at 117-19. For more about Freud's family romance fantasy, see also Elizabeth L. Auchincloss \& Eslee Samberg, Psychoanalytic Terms and Concepts 84-85 (2012).

53. Herman, supra note 24, at 279.

54. Carp, Adoption Politics, supra note 28, at 9. Still, $40 \%$ of states allowed unrestricted access to adult adoptees until the 1960s. Samuels, The Idea of Adoption, supra note 31, at 369.

55. Carp, Adoption Politics, supra note 28, at 12. Carp further reports that by 1979,38 states had sealed such records, with seven more states joining after 1979. Id. at 12 .

56. Cahn \& Singer, supra note 34 , at 157; Herman, supra note 24 , at $143-44$.

57. See Judith S. Modell, A Sealed and Secret Kinship: The Culture of Policies and Practices in American Adoption 24-30 (2002); Paul Sachdev, Unlocking the Adoption Files 1 (1989). 
Association (ALMA), attempted to avoid a fifty-state strategy of seeking reform in each state's legislature by seeking to declare closed records unconstitutional under the federal constitution. ${ }^{58}$ The United States Court of Appeals for the Second Circuit rejected the argument that adult adoptees had a constitutional right to access the sealed information. ${ }^{59}$ In the next phase of the adoptee rights movement, adoptees sought to convince social workers to return to their roots by mandating disclosure, and lobbied legislatures to re-open records. ${ }^{60}$ The movement enjoyed some success with social workers and agency insiders, with many individual adoption agencies, as well as the influential Child Welfare League of America, adopting more liberal policies on disclosure. ${ }^{61}$ Legislative reform, however, was generally unsatisfactory. ${ }^{62}$ While many states legislated a middle ground-establishing voluntary registries where both birth parents and adopted persons could sign up and, if matched, would be provided with identifying information about the other ${ }^{63}$-reformists remained frustrated by legislatures' rejection of unconditional access to adoption and birth information. ${ }^{64}$ Advocacy for open records continues today, but only nine states provide adult adoptees with unconditional access to birth records. ${ }^{65}$ Although open records for adult adoptees

58. See ALMA Soc. Inc. v. Mellon, 459 F. Supp. 912 (S.D.N.Y. 1978), affd, ALMA Soc. Inc. v. Mellon, 601 F.2d 1225 (2d Cir. 1979).

59. See ALMA Soc. Inc. v. Mellon, 601 F.2d 1225 (2d Cir. 1979), cert. denied, 444 U.S. 995 (1979). See Audra Behne, Balancing the Adoption Triangle: The State, the Adoptive Parents and the Birth Parents-Where Does the Adoptee Fit In?, 15 Buff. Jour. Pub. Int. Law 49 (1996/97); Cahn \& Singer, supra note 34, at 155; Samuels, supra note 31, at 373-77. $5-6$.

60. Carp, Adoption Politics, supra note 28, at 23; Sachdev, supra note 57, at

61. Carp, Adoption Politics, supra note 28, at 23; Sachdev, supra note 57, at 5 (in early 1976, the CWLA recommended to its member agencies to inform adoptive parents and birth parents that secrecy could not be permanently guaranteed.).

62. Melosh, supra note 22, at 274.

63. Wegar, supra note 20 , at 18.

64. Carp, Adoption Politics, supra note 28, at 24. Voluntary registries are attractive on the surface, seeming to balance an adoptee's desire to know with a birth mother's desire for privacy. Such registries have proven to be "cumbersome, expensive, and ineffective." Id. at 24. See also Sachdev, supra note 57, at 5.

65. State Legislation, American Adoption Congress, http://www.american adoptioncongress.org/state.php\#top (last visited Mar. 23, 2015) (follow links to Alabama, Alaska, Colorado, Kansas, Maine, New Hampshire, New Jersey, and Oregon). An additional seven states allow for partial access or access with some restrictions. Id. 
have been difficult to achieve, there has been more success in openness in adoption in other ways.

\section{B. Toward Openness in Domestic Adoption}

Open adoption, ordinarily defined as an adoption where the birth family and adoptive family meet before the adoption and have some form of continuing contact after the adoption, ${ }^{66}$ occurred in the early, informal days of domestic adoption, before becoming increasingly closed over time. ${ }^{67}$ In 1964 , sociologist H. David Kirk first proposed what we call open adoption today, suggesting that birth mothers and adoptive parents meet before the adoption and exchange reports and pictures throughout the child's life. ${ }^{68}$ Eleven years later, social science researcher and adoption rights activist Annette Baran presented a paper to a professional conference defining open adoption as follows: "one in which the birth parents meet the adoptive parents, participate in the separation and placement process, relinquish all legal, moral, and nurturing rights to the child, but retain the right to continuing contact and to knowledge of the child's whereabouts and welfare." ${ }^{\text {99 }}$ In addition to psychological benefits of openness, Baran saw instrumental benefits-giving birth mothers the choice of open adoption would make them more willing to place children for adoption. ${ }^{70}$ At the time, the pool of unwed mothers wishing to place a child for adoption had declined dramatically as a result of changing mores concerning unwed births and increased availability of

66. Wolfgram, supra note 4, at 136; Siegel \& Livingston, supra note 4, at 10. The continuing contact in open adoption can vary from mediated exchange of information and photos throughout the child's life to continuing in-person contact between the birth family, the adoptive family, and the child. Id.

67. See discussion, supra, at text accompanying notes 20-54.

68. Carp, Family Matters, supra note 1, at 198; Susan M. Henney, et al., The Impact of Openness on Adoption Agency Practices: A Longitudinal Perspective, 6 Adoption Q. 31, 32 (2003); Sachdev, supra note 57, at 5.

69. Carp, Family Matters, supra note 1, at 198-99. See also Adam Pertman, Adoption Nation: How the Adoption Revolution is Transforming America 63 (2000) (describing the increasing trend of open adoptions); Wegar, supra note 20, at 20 (describing the historical trend towards open adoptions); Henney et al., supra note 68 , at 32 (noting trend of demands of the birthmothers for openness).

70. Carp, Family Matters, supra note 1, at 198-99 (1998). Annette Baran believed that many young single mothers wanted to place their child, but could not face never knowing the child in the future. Annette Baran, et al., Open Adoption, 21 Social Work 97, 98-99 (1976). When open adoption was suggested to them, they felt that adoption was a very good choice for them. Id. at 99. 
contraceptives and abortion. ${ }^{71}$ Non-relative adoptions fell from 89,200 in 1970 to 47,700 in $1975 .^{72}$

Open adoption was spurred during this period of decline in available infants for adoption by the increasing power of birth mothers in the exchange. ${ }^{73}$ "Indeed, with fewer and fewer infants available, the forces of supply and demand provided expectant parents considering adoption more of a say. ${ }^{74}$ Agencies were more likely to listen and respond to desires of birth mothers than during previous eras. ${ }^{75}$ The agencies also had to compete with non-agency private placement adoptions, where the birth parents and adoptive parents found each other and openness of identity was inevitable. ${ }^{76}$ The market response of adoption agencies became part of social work practice, with the professionals crafting a continuum of openness from which birth mothers could choose. ${ }^{77}$ Open adoption grew in practice, and by the mid-1980s, "agencies increasingly provided pictures of the placed child to birthparents, let birthparents select adoptive parents for the child, arranged meetings between birthparents and adoptive parents without sharing identifying information, and offered ongoing contact between parties." ${ }^{\text {id }}$

71. Carp, Family Matters, supra note 1, at 200 (1998); Kristin Luker, Dubious Conceptions: The Politics of Teenage Pregnancy 97 (1996); Siegel \& Livingston, supra note 4, at 12 .

72. Carp, Family Matters, supra note 1, at 200; see also 2-13 Adoption Law and Practice $\S 13.02$ (noting the decline in newborns adopted by nonrelatives). Carol Sanger, Bargaining for Motherhood: Postadoption Visitation Agreements, 41 Hofstra L. Rev. 309, 314 (2012) (quoting the National Committee for Adoption commenting on the decline, "[m]ore than a million couples are chasing the 30,000 white infants available in the country each year.").

73. Melosh, supra note 22, at 277; Sanger, supra note 72, at 314-15.

74. Siegel \& Livingston, supra note 4 , at 12 ; Wolfgram, supra note 4 , at 134.

75. Sanger, supra note 72, at 314-15; Susan M. Henney, et al., The Impact of Openness, supra note 68 , at 32,41 (the number one reasons agencies gave for increasing openness during the 10 years of the study was birth mother demand).

76. Modell, supra note 57, at 61; Melosh, supra note 22, at 278 (noting that no state required confidential adoption, and allowing birth mothers to directly place their children allowed open adoption to be "implemented with ease."); Harold D. Grotevant \& Ruth G. McRoy, Openness in Adoption: Exploring Family Connections 35 (1998).

77. Carp, Family Matters, supra note 1, at 202; Siegel \& Livingston, supra note 4, at 12 (2012); Melosh, supra note 22, at 277.

78. Grotevant \& McRoy, supra note 76 , at 34 . 
As open adoption grew in practice, criticism of open adoption also grew. ${ }^{79}$ Critics argued that open adoption was untested as compared to the longstanding tradition of closed adoptions. ${ }^{80}$ Some argued that birth mothers would never recover from the pain and loss of adoption relinquishment if their contact continued. ${ }^{81}$ Adoptive parents would not securely bond with an adopted child because the presence of birth parents in their lives would threaten their sense of security. ${ }^{82}$ Adopted children would suffer from the insecure attachment of their adoptive parents and would have identity confusion over two sets of parents. ${ }^{83}$ By 1986, open adoption had become a major topic in the social work profession and had started to reach the general public. ${ }^{84}$ In that same year, advocates of open adoption acquired a powerful supporter-the Child Welfare League of America passed a resolution at its biennial meeting endorsing open adoption. ${ }^{85}$ Two years later, the League added a new section to the standards it promulgated to adoption agencies, recommending that open adoption "be an integral part of all adoption services."

\section{Openness Today}

After decades of secrecy in adoption, there is an increasing understanding among adoptive parents, supported by research, that openness of communication about adoption is important to

79. Siegel \& Livingston, supra note 4, at 12-13; Melosh, supra note 22, at 276-77; Wolfgram, supra note 4, at 134-35. For early critics, see A. Dean Byrd, The Case for Confidential Adoption, 46 Pub. Welfare 20 (1988); Deborah Churchman, The Debate Over Open Adoption, 44 Pub. Welfare 11 (1986); Adrienne D. Kraft et al., Some Theoretical Considerations on Confidential Adoptions, Part 1: The Birth Mother, 2 Child \& Adolescent Soc. Work J. 13 (1985).

80. See Carp, Family Matters, supra note 1, at 214 (1998).

81. Kraft et al., supra note 79; Marianne Berry, Risks and Benefits of Open Adoption, 3 Future of Child. 125, 128 (1993); Carys Alty and S. Cameron, Open Adoption-The Way Forward?, 15 Int'l J. Soc. \& Soc. Pol'y 40, 44 (1995).

82. Kraft et al., supra note 79, at 69; Berry, supra note 81 , at 128.

83. Kraft et al., supra note 79, at 139; Berry, supra note 81, at 129 .

84. Carp, Family Matters, supra note 1, at 219 (1998).

85. Carp, Family Matters, supra note 1, at 220; Nancy F. Belbas, Staying in Touch: Empathy in Open Adoptions, 57 Smith C. Stud. in Soc. Work 184, 184 (1987) (reporting conversation with CWLA representative); Annette Baran \& Reuben Pannor, Open Adoption, in The Psychology of Adoption 316, 318 (David M. Brodzinsky \& Marshall D. Schechter, eds. 1990); Michelle Kahan, Put Up on Platforms: A History of Twentieth Century Adoption Policy on the United States, 33 J. Soc. \& Soc. Welfare 51, 66 (2006).

86. Carp, Family Matters, supra note 1, at 220; Kahan, supra note 85, at 66. 
an adopted child's development. ${ }^{87}$ More importantly, research has supported the importance of structural openness in adoption as well. ${ }^{88}$ A longitudinal study examining adoption agency practices in the late 1980s through 1999 found that agencies steadily increased their open adoption practices during that time, and in particular, the availability of fully open adoption. ${ }^{89}$ In fact, by 1999 , none of the agencies studied offered only traditional confidential adoption. ${ }^{90}$ Today, fully two-thirds of private domestic adoptions in America are structurally open, in that there is post-adoption contact between children and their birth families. ${ }^{91}$

Despite early reservations about openness in adoption, "the growing body of research paints a positive picture of how well open adoptions of various forms tend to work for their participants." 92 Studies show benefits for adoptees, adoptive parents, and birth parents.

Even without continuing contact with birth parents, open communication about adoption between adoptees and adoptive parents is beneficial to adoptees. ${ }^{93}$ Adoptees who experienced communicative openness at home about their adoption were less likely to feel different because of their adoption and had higher selfesteem. ${ }^{94}$ Researchers have found a correlation in adoptees between on-going contact with birth parents and qualities such as openness and self-esteem: "the more contact children had with birth family, the

87. Siegel \& Livingston, supra note 4, at 13; Nola Passmore et al., Secrecy Within Adoptive Families and its Impact on Adult Adoptees, Family Relationships Quarterly, no. 5, 2007 at 3, available at http://www.aifs.gov.au/ afrc/pubs/newsletter/n5pdf/n5b.pdf.

88. Siegel \& Livingston, supra note 4 , at 13.

89. Henney et al., supra note 68, at 38; Grotevant \& McRoy, supra note 76, at 25-65.

90. Henney et al., supra note 68 , at $38-39$.

91. Siegel \& Livingston, supra note 4 , at 15 ; Wolfgram, supra note 4 , at 135.

92. Siegel \& Livingston, supra note 4 , at 16 .

93. Amanda Hawkins et al., Communicative Openness About Adoption and Interest in Contact in a Sample of Domestic and Intercountry Adolescent Adoptees, 10 Adoption Q. 131, 132 (2007).

94. Celia Beckett et al., The Experience of Adoption (2): The Association Between Communicative Openness and Self-Esteem in Adoption, 32 Adoption \& Fostering 29, 35 (2008) (study includes both domestically and internationally adopted children); Rachel Levy-Shiff, Psychological Adjustment of Adoptees in Adulthood, 25 Int'l J. Behav. Dev. 97 (2001) (adoptees who could discuss their adoption with their adoptive parents had better self-concept and lower psychopathology). 
more open the communication about adoption within their family and the more positive they felt about themselves. ${ }^{95}$ Adopted children in open adoptions understood that adoption was permanent and felt secure in their relationships with their adoptive parents. ${ }^{96}$ Where children are excluded from contact with birth parents, when such contact is possible, approximately two-thirds expressed concerns about permanence. ${ }^{97}$ Thus, the quality of the relationship adopted children have with their adoptive parents is enhanced by openness. ${ }^{98}$ Openness, including contact with birth parents, shows no negative impact on adolescent adoptees' externalizing behavior, such as lying, violence, and rule-breaking. ${ }^{99}$ Indeed, one study found higher levels of negative externalizing behavior among adolescents in fully confidential adoptions than in fully open adoptions. ${ }^{100}$ Some suggest that openness may be especially important in transracial adoption, where children parented by someone of another race needs same-race role models to help with racial identity formation. ${ }^{101}$ One of the largest longitudinal studies, the Minnesota-Texas Adoption Project, found no negative effects in children in open adoptions. ${ }^{102}$

Empirical studies also show little to support critics' fears about open adoption's effects on adoptive parents. Rather than critics'

95. David Brodzinsky, Family Structural Openness and Communication Openness as Predictors in the Adjustment of Adopted Children, 9 Adoption Q. 1, 10 (2006).

96. Grotevant \& McRoy, supra note 76, at 91-92.

97. Id.

98. See also Margaret Sykes, Adoption with Contact: A Study of Adoptive Parents and the Impact of Continuing Contact with Families of Origin, 24 Adoption \& Fostering 20, 25 (2000) (contact with birth family is helpful in reducing a child's sense of "muddle and confusion," enabling growth of more satisfying relationship with adopters).

99. Harold D. Grotevant, et al., Post-Adoption Contact, Adoption Communicative Openness, and Satisfaction with Contact as Predictors of Externalizing Behavior in Adolescence and Emerging Adulthood, 52 J. Child Psychology \& Psychiatry 529, 533-35 (2011).

100. Lynn Von Korff, et al., Openness Arrangements and Psychological Adjustment in Adolescent Adoptees, 20 J. Family Psychology 531, 534 (2006).

101. Marianne Berry, Adoptive Parents' Perceptions of, and Comfort with, Open Adoption, 72 Child Welfare 231, 234, 246 (1993), (reporting, however, that in her study, adoptive parents in transracial adoptions were no more likely than other adopters to have had contact with biological parents).

102. Siegel \& Livingston, supra note 4, at 16; Harold D. Grotevant, et al., Contact After Adoption: Outcomes for Infant Placements in the USA in Contact, in Adoption and Permanent Foster Care: Research, Theory and Practice 7, 22 (Elsbeth Neil \& David Howe, eds. 2004); Grotevant \& McRoy, supra note 76, at 90-92. 
fears that adoptive parents would feel unable to attach to their children, the Minnesota-Texas Adoption Project found that adoptive parents in open adoptions felt securely attached to their children, as evidenced by their feelings that the relationship was permanent. ${ }^{103}$ Adoptive parents in open adoptions felt as entitled to parent as those in closed adoptions. ${ }^{104}$ While feelings of competition with the birth mother surfaced for some adoptive parents, that feeling reduced with the passage of time. ${ }^{105}$ Adoptive parents in open adoptions show little fear that birth parents might seek to reclaim the child, with parents in fully open adoptions showing the least fear of reclaiming. ${ }^{106}$ Adoptive parents in open adoptions also express satisfaction with open adoption, with "any dissatisfaction tend[ing] to focus around their desire for more, not less, contact with the birthparents." 107 In one study where adoptive parents in open adoptions were interviewed at seven year intervals, while the children were at different developmental stages, adoptive parents reported that "they felt more enthusiasm for and comfort with open adoption" as they had more experience with it. ${ }^{108}$ For adoptive parents, more openness correlates with more satisfaction with the adoption. ${ }^{109}$

Birth mothers also express satisfaction with open adoption arrangements. ${ }^{110}$ Critics' concerns for birth mothers in open adoption have not been borne out in empirical studies:

103. Grotevant \& McRoy, supra note 76, at 90-92.

104. Id. at 127-29. See also Deborah H. Siegel, Open Adoption of Infants: Adoptive Parents' Feelings Seven Years Later, 48 Social Work 409, 417 (2003) (adoptive parents in open adoption "felt empowered in their parental roles by having knowledge of and contact with their children's birth families."); Sykes, supra note 98 , at 21 (continuing contact provided adoptive mothers confirmation in their role as parents, and vetting by birth parent enhanced feelings of parental competence).

105. Sykes, supra note 98, at 26-27.

106. Grotevant \& McRoy, supra note 76, at 129.

107. Id. at 130 . As the study notes, the level of satisfaction here is that of adoptive parents, and adoptive parents and birthmothers in general do not have equal power within their relationship to determine and negotiate openness arrangements." Id. See also Deborah H. Siegel, Open Adoption and Adolescence, 89 Families in Society: J. Contemporary Social Services 366, 372 (2008) (discussing results of study finding that most adoptive parents in open adoptions see openness as an advantage and maintain contact with the birth family).

108. Siegel, supra, note 104, at 416. See also Sykes, supra note 98, at 20.

109. Xiaojia Ge, et al., Bridging the Divide: Openness in Adoption and Postadoption Psychosocial Adjustment Among Birth and Adoptive Parents, $22 \mathrm{~J}$. Family Psychology 529 (2008).

110. Id. (the more open the adoption, the more satisfied the birth mother was with the process and the better the postadoption adjustment of the birth 
Although some critics of openness have suggested that fully disclosed adoptions may lead to competition with the adoptive parents, problems in later adjustment, jealousy toward the adoptive parents, and possibly regret about the decision to place, the majority of birthmothers in this study who are engaged in direct contact with the adoptive families did not express these feelings. Contrary to critics' predictions, the opportunity to see the child with the adoptive family seemed to have a "healing effect." Many claimed they were able to better accept their decision to make an adoption plan once they knew the child was happy. ${ }^{111}$

Birth mothers in fully open adoptions adjusted better to the ambiguous role of birth mother than did birth mothers with no ongoing contact, likely because of feedback from adoptive parents that helped them conceptualize the role of birth mother. ${ }^{112}$ While grief is a natural reaction to relinquishing a child for adoption, resolution of that grief is expected over time. ${ }^{113}$ In one study, birth mothers who played a role in selecting the adoptive parents for their child reported "lower levels of grief, regret, worry, and sadness, and higher levels of relief and peace, than do their counterparts who did not have this opportunity." 114

Birth mothers with continuing contact with their children fared better in grief resolution than did mothers with no continuing contact. ${ }^{115}$ The group that scored worse in grief resolution was birth mothers who initially had continuing contact, but for whom the

mother); Ruth G. McRoy, et al., Open Adoptions: Longitudinal Outcomes for the Adoption Triad, in Handbook of Adoption: Implications for Researchers, Practitioners and Families 175, 180 (Rafael A. Javier, et al., eds., 2007).

111. Grotevant \& McRoy, supra note 76, at 144-45.

112. Id. at 161 .

113. Susan M. Henney, et al., Evolution and Resolution: Birthmothers' Experience of Grief and Loss at Different Levels of Adoption Openness, 24 J. Social \& Personal Relationships 875, 876, 882, 885 (2007) (noting, however, that even 12 to 20 years after placement, most birth mothers in their research sample continued to experience at least some feelings of grief and loss related to the adoption).

114. Linda F. Cushman, et al., Openness in Adoption, 25 Marriage \& Family Rev. 7, 14 (1997).

115. Grotevant \& McRoy, supra note 76, at 169. See also Cinda L. Christian, et al., Grief Resolution of Birthmothers in Confidential, Time-Limited Mediated, Ongoing Mediated, and Fully Disclosed Adoptions, 1 Adoption Quarterly 35, 52 (1997) (reporting that four to twelve years after placement, birth mothers with ongoing contact showed better grief resolution than birth mothers whose contact has stopped). 
contact ceased. ${ }^{116}$ The researchers hypothesized that the cessation of contact would be felt as an additional loss, "which could exacerbate grief associated with making the adoption plan."117

Despite the good news about open adoptions painted in the empirical research, there are still significant problems with ensuring openness in American domestic adoptions. In many studies about open adoption, researchers note that openness changes over time. ${ }^{118}$ While those changes may mean increased openness, ${ }^{119}$ often they mean that informal agreements for openness are not honored and that adoptions close over time ${ }^{120}$ Once a birth parent's legal rights as a parent have been terminated to make way for the adoption, there is no legal right for continuing contact. ${ }^{121}$ In a majority of states, open adoption agreements are not legally enforceable. ${ }^{122}$ In those states

116. Grotevant \& McRoy, supra note 76, at 169. See also Henney, et al., Evolution and Resolution, supra note 113, at 884 (birth mothers in confidential adoptions had the highest grief score, followed by those who once had openness that ceased).

117. Grotevant \& McRoy, supra note 76, at 169.

118. Siegel, supra note 104, at 417 ; Henney et al., supra note 113 , at 876 , 883 (2007).

119. Marianne Berry, et al., The Role of Open Adoption in the Adjustment of Adopted Children and Their Families, 20 Children \& Youth Services Rev. 151, 169 (1998) (while contact decreased or ceased for $44 \%$ of participants, it increased for only $4 \%$ of participants); Henney et al., supra note 113 , at $875,883-84$ (in the study, $58 \%$ of birth mothers experienced an increase in openness level over time, while $42 \%$ experienced a decrease in openness level).

120. Berry et al., supra note 119 , at 151 (saying that openness has decreased or ceased over time, especially in families who chose openness initially at the insistence of agency); Thomas M. Crea \& Richard P. Barth, Patterns and Predictors of Adoption Openness and Contact: 14 Years Postadoption, 58 Family Relations 607, 615 (2009) (saying that post-adoption contact decreases over time). But see Jeanne Etter, Levels of Cooperation and Satisfaction in 56 Open Adoptions, 72 Child Welfare 257 (1993) (an average of four-and-a-half years after the adoption, high compliance $(\mathbf{9 8 . 2 \%})$ with written adoption agreements for contact).

121. See Malinda L. Seymore, 16 and Pregnant: Minors' Consent to Abortion and Adoption, 25 Yale J. L. \& Fem. 99, 153 (2013).

122. Child Welfare Information Gateway, U.S. Dep't. of Health and Human Servs., Postadoption Contact Agreements Between Birth and Adoptive Families (2011), available at https://www.childwelfare.gov/systemwide/laws_policies/ statutes/cooperative.pdf. See also Annette Ruth Appell, Blending Families Through Adoption: Implications for Collaborative Adoption Law and Practice, 75 B.U. L. Rev. 997, 1023 (1995) (describing the limitations of court enforcement of post-adoption contact agreements); Annette Ruth Appell, Reflections on the Movement Toward a More Child-Centered Adoption, 32 W. New Eng. L. Rev. 1, 5 (2010) (describing two types of regulatory schemes that sanction and enforce post-adoption contact); Cynthia E. Cordle, Open Adoption: The Need for 
where open adoption agreements are enforceable, they are only enforceable when the intricacies of the effective statutes are followed, ${ }^{123}$ or in only some adoptions, or between only some parties. ${ }^{124}$ "It is still common practice in states without enforceable open-adoption agreements, however, for agencies and adoptive parents to enter into such unenforceable 'agreements."'125 Agencies in states that have no legal enforcement of open adoption agreements still tout the availability of open adoption, as if it is guaranteed. ${ }^{126}$

Despite these issues, the promising effects of open adoption in American open adoption arrangements is at least one motivating factor in the interest in increased openness in international adoption.

\section{LEGAL FRAMEWORK SUPPORTING OPENNESS IN INTERNATIONAL ADOPTION}

\section{A. Emerging Openness in International Adoption}

The current understanding of international adoption is that all international adoptions are closed adoptions. ${ }^{127}$ There is, however,

Legislative Action, 2 Va. J. Soc. Pol'y \& L. 275, 275 (1995) (noting that “[o]nly a couple of state statutes explicitly permit postadoption visitation by natural parents"); Amy L. Doherty, Foster Care and Adoption: A Look at Open Adoption, 11 J. Contemp. Legal Issues 591, 594 (1997) (summarizing the open adoption laws in the various States); Leigh Gaddie, Open Adoption, 22 J. Am. Acad. Matrimonial Laws. 499, 503 (2009) (stating that many states allow for enforceable open adoptions in limited circumstances).

123. Seymore, supra note 121, at 153.

124. Id.

125. Id. at 151 .

126. Id. at 151-52 (describing internet offerings from adoption agencies in non-enforcement states promising birth mothers continuing contact post-adoption).

127. See Child Welfare Information Gateway, Searching for Birth Relatives, 9-10 (2011), https://www.childwelfare.gov/pubs/f_search.pdf; Howard, supra note 14; Harold D. Grotevant, Openness in Adoption: Rethinking Family in the U.S., in Reproductive Disruptions: Gender, Technology and Biopolitics in the New Millennium 122, 126 (Marcia C. Inhorn ed., 2008) ("Many assume that in international adoptions, contact with the child's birth family is impossible. This is true in some cases, especially for children who were adopted from orphanages after they have been abandoned."); Fleisher, supra note 8, at 191 ("There are no open intercountry adoptions."); Kim, supra note 5, at 142 ("One of the most prevalent reasons for adopting foreign-born babies is the idea that transnational adoptions are closed transactions."). 
a growing interest in increased openness in international adoption. ${ }^{128}$ Even some adoption agencies are recognizing the importance of continuing birth-family contact for internationally adopted children and facilitating such contact where possible. ${ }^{129}$ These are all marked changes from the early days of international adoption.

Indeed, a virtual cottage industry of birth parent searchers has sprung up in international adoptions. One company promises help in finding and contacting birth parents "if the birth parents of your adopted child are from the areas of Kazakhstan, Russia, Ukraine, Armenia, Georgia, Moldova, Belarus, Krygyzstan, any other former Soviet Union countries, Bulgaria, Romania, Colombia, Costa Rica or Guatemala." ${ }^{130}$ A Russian/English translator also offers searching help: "I have assisted adoptive families to successfully find their children's birthmothers. I can help with locating, composing letters, and sending scanned photos via registered mail to your child's biological mother." ${ }^{131}$ Another website offers the following services: "With our more than 10 years of experience gathering information, statistics, and insight into China adoptions, we offer an Orphanage Reliability Analysis to help determine the accuracy of your child's orphanage information and a Birth Parent Search Analysis to help you decide whether or not to pursue a search for your child." ${ }^{132}$ Even adoptive parents who have successfully searched now offer to help others search:

My name is Mary an adoptive parent. I have adopted a daughter from Russia. I recently made contact with her Russian birthmother and Russian family members. Through my search I have made many contacts. I would now like to help others who are considering searching for their own Russian birthmother." ${ }^{133}$ In Ethiopia, birth parent searchers, hired by adoptive parents, have uncovered cases of

128. Child Welfare Information Gateway, supra note 127, at 9 (noting the increase in birth parent searches in international adoption); Howard, supra note 14 , at 1 .

129. Grotevant, supra note 127 , at 126.

130. International Adoption Search Birth Families LLC, http://internationaladoptionsearch.com/ (last visited Feb. 10, 2015).

131. Victor Sluczewski, Contact Family Members in Russia and Russian Language Countries, Russian/English Translator for Hire, http://www.debryansk.ru/ vls/birthf.htm (last visited Feb. 10, 2015).

132. Research-China.org, http://www.research-china.org/ (last visited Mar. 1, 2015).

133. RussianFamilySearch.com, http://www.russianfamilysearch.com/ (last visited Mar. 1, 2015). 
fraud and corruption that have led to threats of violence from adoption agencies. ${ }^{134}$

There has been very little empirical study of openness in international adoption because of the newness of the phenomenon. ${ }^{135}$ One study has focused on a small cadre of American adoptive parents who have adopted children from the Marshall Islands, an American Protectorate. ${ }^{136}$ The adoption situation in the Marshall Islands appears unique, with adoption agencies advocating openness in adoption, in accordance with the customary understanding of adoption in the Marshall Islands. ${ }^{137}$ Thus, adoptive parents enter the adoption program expecting some form of continuing contact with the birth family. ${ }^{138}$ When asked their feelings upon first learning that the Marshall Islands program would include openness, $68 \%$ of prospective adoptive mothers and $67 \%$ of prospective adoptive fathers said they had positive or very positive reactions to open adoption. ${ }^{139}$ In fact, $52 \%$ of the couples stated that "continuing contact strengthened the parents' desire to adopt from the Marshall Islands." 140

Most adoptive parents reported that they did not have direct contact with the birth family to formulate an open adoption agreement, but that a facilitator did so for them. ${ }^{141}$ It is perhaps unsurprising, then, that the adoptive parents had various

134. Kathryn Joyce \& Michael Tsegaye, Who's Intimidating Ethiopia's Adoption Searchers?, Pulitzer Center on Crisis Reporting (Jan. 5, 2012), http://pulitzercenter.org/reporting/ethiopia-adoption-program-searchers-

intimidation-corruption-fraud; Kathryn Joyce, Adoption Inc.: How Ethiopia's Industry Dupes Families and Bullies Activists, Pulitzer Center on Crisis Reporting (Dec. 21, 2011), http://pulitzercenter.org/reporting/ethiopiainternational-adoption-program-ethics-birth-families-activists.

135. See supra text accompanying notes 86-116 (discussing open adoption research in the United States).

136. Jini L. Roby et al., Openness in International Adoptions: A Study of U.S. Parents Who Adopted Children from the Marshall Islands, 8 Adoption Q. 47 (2005).

137. Id. at 51. See also Roby \& Matsumura, supra note 8, at 7 (documenting a similar study from the perspective of birth mothers); Irving G. Leon, Adoption Losses: Naturally Occurring or Socially Constructed?, 73 Child Development 652, 657-58 (2002) (discussing traditional adoption in the "Pacific islands of Oceania," an area that encompasses the Marshall Islands, where "adoption rarely occurred anonymously, and typically involving ongoing interaction between biological and adoptive parents.").

138. Roby et al., supra note 136, at 51 .

139. Id. at 56.

140. Id. at 57.

141. Id. at 58-59. 
understandings of what kind of contact had been promised-from exchange of letters and pictures to in-person visits, and varying contact in between. ${ }^{142} \mathrm{~A}$ majority of the adoptive parents considered the agreements morally binding, but knew they were in no way legally binding. ${ }^{143} \mathrm{~A}$ majority of adoptive parents said that the level of contact agreed upon had been continued or increased, while $32 \%$ said that the level of contact had decreased over time, the main reason being the unreliability of mail contact in the Marshall Islands, language barriers, lack of an intermediary, or not having the birth parents' address. ${ }^{144}$ Adoptive parents reported that they would, in retrospect, make the same decision to adopt from the Marshall Islands today, and that the open adoption arrangement had been positive for their families. ${ }^{145}$

Open adoption studies of birth mothers in international adoption are also sparse. ${ }^{146}$ Jini Roby, who studied adoptive parents who adopted from the Marshall Islands, has also studied birth mothers from the Islands. ${ }^{147}$ She has found that the cultural understanding of adoption in the Marshall Islands is very different from the Western understanding and that an "astounding number of the birthmothers (82.2\%)" believed when they relinquished their child, that the child would return to them at age eighteen, well-educated and wealthy. ${ }^{148}$ Almost seventy percent believed at the

142.

Id. at 60-61.

143. Id. at 61.

144. Id.

145. Id. at 61-62. The only other study of openness in international adoption from the view of adoptive parents is a small (eight adoptive mothers) study of adoptive mothers who met birth mothers while adopting from Romania in 1990 and 1991. Roberta Goldberg, Adopting Romanian Children: Making Choices, Taking Risks, 25 Marriage \& Family Rev. 79 (1997). Adoptive mothers gained information about birth mothers from "official documents and meeting face to face in court." Id. at 88 . It does not appear, however, that the majority of adoptive mothers kept in contact with the birth families after the adoptions-only one mother said she had corresponded with the birth mother and another said she planned to do so. Id. at 94. Most of the mothers expressed a desire to return with their children to Romania "one day," though they were less certain about whether they would want their children to meet their birth mothers. Id.

146. In fact, any information about birth mothers in international adoption is scant. See Amanda L. Baden, et al., International Adoption: Counseling and the Adoption Triad, 16 Adoption Quarterly 218, 219 (2013) ("Birth parents remain the most under-represented members of the adoption triad; birth parents of IA adoptees, doubly so.").

147. Roby \& Matsumura, supra note 8, at 7.

148. Id. at 22. See Baden et al., supra note 146, at 218 (literature review found reports of different cultural understandings of adoption among birth 
time of relinquishment that the child would be returned to them if the adoption didn't work out. ${ }^{149}$ At the time of the interviews, only 28.8\% still believed their child would return, because promised letters, pictures, and monetary gifts were never received or stopped. ${ }^{150}$

There have been many studies of international adoptees but little about openness in their adoptions given the newness of the phenomenon. There have been studies of international adoptees exploring issues of cultural, ethnic, and racial identity formation and examining why international adoptees search for birth relatives, make homeland visits, and/or learn the language of their country of origin as part of that identity formation. ${ }^{151}$

Because of the importance and complexity of identity formation for international adoptees, that topic has been frequently explored.

[I]dentity is part of human cognitive and emotional development through which a person begins to understand him-or-herself as separate from but related to others: as a person who has a past, present,

mothers in South Africa and India (citing Pien Bos, Once a Mother: Relinquishment and adoption from the perspective of unmarried mothers in south India (Nov. 2007), available at http://repository.ubn.ru.nl/bitstream/ handle/2066/73643/73643.pdf?sequence=1.)); Riitta Hogbacka, Maternal thinking in the context of stratified reproduction: Perspectives of birth mothers from South Africa, in Intercountry Adoption: Policy, Practice \& Outcomes 143 (J.L. Gibbons \& K.S. Rotabi eds., 2012); Kay Johnson has interviewed birth mothers in China about their decisions to abandon children who make their way into both domestic and international adoption. Kay Ann Johnson, Wanting a Daughter, Needing a Son: Abandonment, Adoption, and Orphanage Care in China (2004). See also Laurel Kendall, Birth mothers and imaginary lives, in Cultures of Transnational Adoption 162 (Toby Alice Volkman ed., 2005) (sharing stories from two Korean birth mothers).

149. Roby \& Matsumura, supra note 8, at 23.

150. Id. at 22 .

151. See Wendy Tieman et al., Young Adult International Adoptees' Search for Birth Parents, 22 J. Family Psychology 678, 678 (2008); Iris Chin Ponte et al., Returning to China: The Experience of Adopted Chinese Children and Their Parents, 13 Adoption Q. 100, 102 (2010) (adoptive parents were motivated to take the trip with their children to learn more details of their children's pasts); Kim, supra note 5, at 115 ("Many adoptee narratives express a yearning . . . to travel to South Korea, to explore cultural and biological "roots," and perhaps to locate missing pieces of the self."); Sarah J. Shin, Language Learning as Culture Keeping: Family Language Policies of Transnational Adoptive Parents, Int'l Multilingual Research J. (July 18, 2014) http://dx.doi.org/10.1080/ 19313152.2014.911052 (knowledge of birth language figures prominently in adoptees' exploration of roots). 
and future-a person with race, ethnicity, sex, gender, likes, dislikes, and personal experiences, and other aspects of one's sense of self. ${ }^{152}$

As additional layers of "difference" are added, identity formation becomes increasingly complex. ${ }^{153}$ Not surprising, then, identity formation can be especially complex for adopted persons:

As they attempt to integrate past with future, they are hindered by the existence of two sets of parents; they experience an absence of generational sequence as a consequence of unrootedness . . . . Adoptees not only must form a synthesis of past and future, but must also integrate the now with those parts of self that have been left in the past. ${ }^{154}$

Adopted adolescents in particular struggle with questions about their origins. Beginning in elementary school and extending into adolescence, adopted children feel a sense of not just losing their birth parents, but of losing a part of themselves. ${ }^{155}$ "[A]dopted adolescents share the tasks of identity development with their non-adopted peers, but have the additional challenge of integrating their history as an adopted person into their emerging sense of identity." ${ }^{56}$ One scholar coined the term "genealogical bewilderment" to describe the difficulty of identity formation for adoptees who had no information about their biological heritage. ${ }^{157}$ A prominent adoptee

152. Annette R. Appell, The Endurance of Biological Connection: Heteronormativity, Same-Sex Parenting and the Lessons of Adoption, 22 BYU J. Pub. L. 289, 292 (2008); Janet L. Hoopes, Adoption and Identity Formation, in The Psychology of Adoption 144, 145 (David M. Brodzinsky \& Marshall D. Schechter eds., 1990).

153. Harold D. Grotevant, Coming to Terms with Adoption: The Construction of Identity from Adolescence into Adulthood, 1 Adoption Q. 3, 8 (1997).

154. Hoopes, supra note 152 , at 149 (quoting Goebel, B. \& Lott, S.L., Adoptees' resolution of the adolescent identity crisis: Where are the taproots? (1986), Paper presented at Am. Psychological Ass'n Meeting (Washington, D.C.)); Harold Grotevant et al., Adoptive Identity, supra note 10, at 381; Gill Pugh, Unlocking the Past: The Impact of Access to Barnardo's Childcare Records 101 (1999).

155. Hoopes, supra note 152, at 149-50.

156. Grotevant, Coming to Terms with Adoption, supra note 153, at 9.

157. Id. at 8 , noting the difficulty in identity formation when adoptees have little or no information about birth parents, raising questions such as "Who is my birthfamily?" and "How am I similar to and different from my birthparents? Where do I fit in their world? How does their world fit into mine?" 
activist calls it "cosmic loneliness." 158 The "dual identity" problem of people with two sets of parents may cause them to "search out their past and pursue information about this unknown self in an effort to resolve the break in the continuity of their lives." ${ }^{159}$

Ethnic or racial identity formation can be a further challenge for international adoptees who do not share their adoptive family's ethnic or racial background. ${ }^{160}$ "The ethnic identity of transracially and internationally adopted children may be thought of as a feeling of connection with both one's cultural past and one's present adoptive heritage." 161 The formation of a positive ethnic or racial identity is important for developing "positive self-esteem and some protection from negative societal stereotypes." ${ }^{162}$ And international, transracial

158. Betty Jean Lifton, Journey of the Adopted Self: A Quest for Wholeness 46-47 (1994): "Connected to his adoptive home by the fragmentary adoption narrative and disconnected from his real biological narrative, he has lost his place on the intergenerational chain of being. I call this cosmic loneliness." See also David M. Brodzinsky, et al., Being Adopted: The Lifelong Search for Self 11-12 (1992) ("Adoptees who are placed in the first days or weeks of life grieve not only for the parents they never knew, but for the other aspects of themselves that have been lost through adoption: the loss of origins, of a completed sense of self, of genealogical continuity.").

159. Hoopes, supra note 152, at 160; Grotevant, Coming to Terms with Adoption, supra note 153, at 11-12; Leon, supra note 137, at 656 (positing that the primary motivation in active searches for birth parents is "filling in the missing pieces of one's genetic background and acquiring a clear history of one's biological family.").

160. Susan A. Basow et al., Identity Development and Psychological Well-Being in Korean-Born Adoptees in the U.S., 78 Am. J. Orthopsychiatry 473, 473 (2008); Oh Myo Kim et al., Cultural Socialization in Families with Adopted Korean Adolescents: A Mixed-Method, Multi-informant Study, 28 J. Adolescent Research 69, 72 (2013); Grotevant, Coming to Terms with Adoption, supra note 153 , at 8 .

161. Nam Soon Huh \& William J. Reid, Intercountry, Transracial Adoption and Ethnic Identity: A Korean Example, 43 Int'l Social Work 75, 75 (2000); Danielle E. Godon et al., Transracial Adoptees: The Search for Birth Family and the Search for Self, 17 Adoption Q. 1 (2014); see generally Mia Tuan \& Jiannbin Lee Shiao, Choosing Ethnicity, Negotiating Race: Korean Adoptees in America (2011) (examining the experience of Korean adoptees adopted by white families in the U.S.); see generally John D. Palmer, The Dance of Identities: Korean Adoptees and Their Journey Toward Empowerment (2011) (examining identity development of Korean adoptees and 1.5 generation Korean-Americans).

162. Basow et al., supra note 160 , at 473 . Even when there are no racial differences between international adoptees and adoptive parents, adoptees still have challenges in ethnic and cultural identity. Rhoda Scherman \& Niki Harré, Interest in and Identification with the Birth Culture: An Examination of Ethnic Socialization in New Zealand Intercountry Adoptions, 53 Int'l Social Work 528, 
adoptees must develop a positive racial identity while still grappling with adoptive identity. ${ }^{163}$ Cultural identity, as well as racial identity, may also depend on location-in one study, a young adult adopted to Sweden from Ethiopia reported feeling more Ethiopian than Swedish while in Sweden, but more Swedish than Ethiopian when in Ethiopia. ${ }^{164}$

Searching for birth parents was once seen as a sign of mental or emotional problems, ${ }^{165}$ an "indicator of an unsuccessful adoption." 166 Now, searching is thought to be a normal part of adoptee identity development. ${ }^{167}$ While those who search are as psychologically well-adjusted as their non-searching peers, they do tend to have lower self-esteem and higher incidence of identity problems. ${ }^{168}$ It is estimated that between $40 \%$ and $50 \%$ of domestic adoptees search for birth family, though the difficulty in accessing closed adoption records may sway some from searching despite a desire to do so. ${ }^{169}$

The process of searching is particularly difficult for international adoptees, who face barriers of language, cultural

537 (2010) (noting differences in interest in birth culture and ethnic identification in racially-congruent adoptive families).

163. Basow et al., supra note 160, at 474, (citing Harold D. Grotevant, Assigned and chosen identity components: A process perspective on their integration, in Adolescent Identity Formation 73 (G. D. Adams et al. eds., 1992)); Femmie Juffer \& Wendy Tieman, Being Adopted: Internationally Adopted Children's Interest and Feelings, 52 Int'l Social Work 635, 640-41(2009) (noting that children adopted from India and China expressed a desire to be white or not to be Chinese/Indian at around age 5).

164. See Grotevant et al., Adoptive Identity, supra note 10, at 384, (citing Barbara Yngvesson, Geographies of Identity in Transnational Adoption, Paper presented at "Mine, Yours, Ours \& Theirs - Adoption and Changing Kinship and Family Patterns" Conference (Oslo 1999)). See also Barbara Yngvesson \& Maureen A. Mahoney, 'As One Should, Ought and Wants to Be': Belonging and Authenticity in Identity Narratives, 17 Theory, Culture \& Society 77, 84 (2000) (referencing a Swedish documentary about an Ethiopian adoptee who moved back to Ethiopia because she felt that was where she "belonged" and she felt "more comfortable" there than in Sweden).

165. See discussion, supra at text accompanying notes 51-53.

166. Tieman et al., supra note 151 , at 678 .

167. Id.; Hoopes, supra note 152, at 160; Grotevant, Coming to Terms with Adoption, supra note 153, at 11-12.

168. Tieman et al., supra note 151, at 678.

169. Id.; Gretchen Miller Wrobel et al., Adoptees' Curiousity and Information-Seeking about Birth Parents in Emerging Adulthood: Context, Motivation and Behavior, 37 Int'l J. Behavioral Development 8 (2013). 
differences, and distance. ${ }^{170}$ Legal systems in the country of origin may make adoption records confidential as well. ${ }^{171}$ In one large-cohort study from the Netherlands, the percentage of international adoptee searchers was lower than the figures given for domestic adoptees who search, at only $31.6 \%$. However, there were an additional $32 \%$ who were not searching, but were interested in doing so. ${ }^{172}$ These figures lead to the possibility that it is the difficulty of international searching, not a lack of interest, that has suppressed the number of searchers. ${ }^{173}$ "[A]doptees from countries in which searching was more difficult-India, Bangladesh, Lebanon and Colombia-had a greater preoccupation with biological origins than adoptees from other countries." 174 Thus, increased openness of adoption records in sending countries would make searching easier for international adoptees.

One scholar has argued that the landscape for searching international adoptees has changed sufficiently so that concerns about identity and culture are misplaced. After all, "[i]f internationally adopted children experience anxiety about their birth families or their national or cultural heritage, they have many more opportunities to explore their past and engage with their birth culture than past generations of adopted children have had." this position shows a considerable lack of understanding of the process of adoptive, racial, and cultural identity formation for international adoptees; to reference the problem as one of mere "anxiety," sounds quite dismissive of the process. Secondly, the changing landscape has not affected many sending countries. While conceding that the change has been slower in some places than in others, the author states that '[t]he 'paper trail' for adoption is improving throughout the world" and that "the advent of open adoption has made birth records more accessible." ${ }^{176}$ But her only

170. Tieman et al., supra note 151 , at 679 .

171. Id.; Bos, supra note 148.

172. Tieman et al., supra note 151 , at 679 .

173. Id.

174. Id.; see also Wrobel et al., supra note 169, at 441, noting in the context of domestic U.S. adoption that external barriers to searching, including lack of access to records, may increase or decrease interest in information-seeking about birth family, depending on how the barrier is perceived. Id. at 442 . For many in the study, external barriers to information-seeking (like agency policies of non-disclosure, adoptive parent resistance, or closed adoption records) increased curiosity. Id. at 448 . See also Leon, supra note 137, at 655 (noting that secrecy in adoption "would likely increase loss of (and shame about) one's birth family, thereby impairing self-esteem and magnifying losses to the self.").

175. Failinger, supra note 17, at 567-68.

176. Id. 
authority for these propositions are articles that do not, in fact, describe improved paper trails for international adoptees or that open adoption has affected the birth records of international adoptees. ${ }^{177}$ And thirdly, while it is true that globalization and the internet has made it easier for international adoptees in terms of cultural experiences of their birth countries, it certainly has not made it easy.

\section{B. Regulating International Adoption Generally}

When Harry Holt decided to adopt eight South Korean children and bring them home to Oregon, the process of international adoption was essentially unregulated. ${ }^{178} \mathrm{Holt}$, as a private citizen, sought permission from the South Korean government to adopt the children, and then petitioned the U.S. Congress for permission to bring them home. ${ }^{179}$ During this period, private, often religiously-

177. Id. (citing Jaci L. Wilkening, Intercountry Adoption Act Ten Years Later: The Need for Post-Adoption Requirements, 72 Ohio St. L.J. 1043, 1049-50, 1054-55 (2011); David M. Smolin, Child Laundering as Exploitation: Applying Anti-Trafficking Norms to Intercountry Adoption Under the Coming Hague Regime, 32 Vt. L. Rev. 1, 9-10 (2007)). Professor Smolin's article, though focused on international adoption, is describing open adoption and original birth records in the United States, not in sending countries. Failinger supra note 17, at 567-68 (citing Smolin at 9-10). In her student note, on the pages cited by Professor Failinger, Jaci Wilkening describes the reporting requirements of the Hague Convention, Wilkening, supra, at 1049-50, which does not establish that the reports are shared with adoptees, have identifying information, are accurate, nor would the Hague reporting requirements be helpful in international adoptees' birth parent searches if they were adopted before the Hague Convention was drafted in 1993. The other reference that Wilkening makes is to the "incomplete medical records" in international adoption. Id. at 1054. Further, Wilkening posits the inaccuracy of records in sending countries, not improved record-keeping from years past: "In many foreign countries where children are available for adoption, 'health care systems and training, record-keeping, and legal surrender procedures, to name just a few items, do not even remotely approach or resemble Western standards." Id. at 1054.

178. Trevor Buck et al., International Child Law 243-44 (2d ed. 2011). Harry and Bertha Holt, who later founded Holt International adoption agency, are credited with the first adoptions from Korea in the 1950s. Karen Dubinsky, Babies Without Borders: Adoption and Migration Across the Americas 94 (2010). Motivated by a documentary about Amerasian children in Korean orphanages, Harry Holt lobbied Congress for a law allowing such adoptions and adopted eight Korean orphans. Barbara A. Moe, Adoption 157 (2d ed. 2007). Holt International "remains one of the largest international adoption agencies in the country." Laura Briggs \& Diana Marre, Introduction: The Circulation of Children, in International Adoption: Global Inequalities and the Circulation of Children 1, 6 (Diana Marre \& Laura Briggs eds., 2009); Tuan \& Shiao, supra note 161, at 21.

179. Moe, supra note 178 , at 157; Briggs \& Marre, supra note 178 , at 6 . 
affiliated, agencies made their own rules for international adoption, with little to no oversight from governments. ${ }^{180}$ As international adoption grew, it was first governed by States' private international law, an often problematic situation: "receiving States lacked information regarding the conditions under which the adoption took place in the countries of origin. Conversely, States of origin had limited information on the development of their children adopted abroad." 181 There was affirmative resistance to nationwide regulation of international adoption from agencies and social workers, and regulation in the United States as a receiving country was left to the various states. ${ }^{182}$

In the 1960s, the Hague Conference on Private International Law sought to regulate international adoption. It introduced the Convention on Jurisdiction, Applicable Law, and Recognition of Decrees Relating to Adoptions. One commentator has noted the perceived novelty of the enterprise: "two things seemed novel about this Convention: first, that its scope was limited to intercountry adoptions; and second, the use of the phrase inter-country adoption." 183 The Convention had but limited success-it was only ratified by three countries: Austria, Switzerland, and the United Kingdom. ${ }^{184}$

International human rights law came late to the regulation of international adoption. ${ }^{185}$ The first draft of the Convention on the Rights of the Child ("CRC"), submitted to the U.N. Commission on Human Rights, did not have any provisions directly addressing

180. Buck et al., supra note 178, at 244-45 (noting that agencies resisted regulation, believing that "the welfare of adoptive children necessitated minimum standards of investigation placement, and supervision conducted only by social work professionals.").

181. Sylvain Vite \& Herve Boechat, A Commentary on the United States Convention on the Rights of the Child Article 21: Adoption 14 (2008).

182. Buck et al., supra note 178 , at 245 .

183. Id.

184. Vite \& Boechat, supra note 181 , at 14 n.35 (these three states, which ratified this convention, denounced it when they adopted the 1993 Hague Convention).

185. Buck et al., supra note 178 , at 244 , (noting the slow growth of international human rights law and the even slower recognition of international children's rights law as hampering the development of international law on intercountry adoption). See also Sonja Starr \& Lea Brilmayer, Family Separation as a Violation of International Law, 21 Berkeley J. Int'1 L. 213, 216-18 (2003), (noting that consideration of family rights of any kind in international law was a late development). 
adoption. ${ }^{186}$ This is perhaps not surprising since the CRC was inspired by the U.N. Declaration on the Rights of the Child, which also failed to address adoption specifically. ${ }^{187}$ Barbados and Colombia first mentioned that adoption should be addressed in the CRC, and their comments served as the origins of Article 21 of the CRC, which first proposed requirements for international adoption. ${ }^{188}$ The CRC was not adopted by the U.N. General Assembly until $1989 ;{ }^{189}$ in the meantime, the U.N. Declaration on Social and Legal Principles Relating to the Protection and Welfare of Children, with Special Reference to Foster Placement and Adoption Nationally and Internationally was promulgated in $1986 .{ }^{190}$ There are also regional and bilateral agreements between States that regulate the international adoption process between those States. ${ }^{191}$

Private international law re-entered the regulatory field with the Hague Convention on the Protection of Children and Co-operation in Respect of Intercountry Adoption, promulgated in 1993. This convention was considerably more successful than the Hague Conference's attempt to regulate international adoption in the $1960 \mathrm{~s}$, with ninety-three signatory States at the time of this writing. ${ }^{192}$ As one scholar describes it, the Hague Convention "took the lofty ideals of the U.N. Convention [on the Rights of the Child] into the arena of nitty gritty detail relevant to States 'sending' and 'receiving' children in this multicultural exchange of human beings." 193

186. Vite \& Boechat, supra note 181, at 3.

187. Id. at 7 .

188. Id. at 3 .

189. Ursula Kilkelly, Using the Convention of the Rights of the Child in Law and Policy: Two Ways to Improve Compliance, in The Human Rights of Children: From Vision to Implementation 179 (Antonella Invernizzi \& Jane Williams eds., 2011).

190. Vite \& Boechat, supra note 181, at 7.

191. Id. at 10-14. See Benyam D. Mezmur, From Angelina (to Madonna) to Zoe's Ark: What are the A-Z Lessons for Intercountry Adoptions in Africa?, 23 Int'l J. Law Policy Family 145 (2009) (discussing international adoption and the effect of African Charter on the Rights and Welfare of the Child); Cheryl L. Allen, The US-Russian Child Adoption Agreement: An End to Failed Adoption?, 35 Fordham Int'l L.J. 1690 (2012) (discussing a recent bilateral agreement between the U.S. \& Russia concerning adoptions between the two countries).

192. The World Organisation for Cross-border Co-operation in Civil and Commercial Matters,_Members of the Organisation, Hague Conference on Private International Law (Jan. 6, 2014), http://www.hcch.net/index_en.php? act $=$ conventions. status\&cid $=69$.

193. Alexandra Maravel, The U.N. Convention on the Rights of the Child and the Hague Conference on Private International Law: The Dynamics of Children's Rights through Legal Strata, 6 Transnat'l L. \& Contemp. Probs. 309, 
What accounts for the greater success of the Hague Convention of 1993 than the first attempt by the Hague Conference to regulate intercountry adoption? The changing landscape of international adoption in the thirty years between the two instruments spurred States to sign on to a convention that did not seem as important before. The growth of intercountry adoption between 1965 and 1993 was part of that changing landscape, but so too was the growth in fraud, corruption, and trafficking in international adoption. ${ }^{194}$

The CRC and the Hague Convention have, together, created the regulatory framework for international adoption. The Hague Convention and Article 21 of the $\mathrm{CRC}$ both require that adoptions be in the best interests of the child, with the CRC saying that best interests "shall be the paramount consideration." 195 Indeed, "this is the only place in the CRC where the best interests of the child are 'the,' and not 'a,' primary consideration." 196 The Hague Convention lists as a primary objective: "to establish safeguards to ensure that intercountry adoptions take place in the best interests of the child."197

Article 21 of the CRC deals with domestic adoption as well as international adoption. Its first part is generally applicable to all adoptions, noting first that it applies to "State Parties that recognize and/or permit the system of adoption." ${ }^{198}$ The article then states the

319 (1996). Of course, it would be more accurate to say the exchange of human beings for money, since international adoption is not a person-for-person exchange.

194. Buck et al., supra note 178, at 247-48, (noting that oftentimes "children are put up for intercountry adoption in a manner that implicates profit, rather than the best interests of the child").

195. CRC, supra note 18, Art. 21.

196. Vite \& Boechat, supra note 181, at 24, citing UNICEF, Innocenti Digest No. 4, Intercountry Adoption, o.c. (note 1), p.5.

197. Hague Convention, supra note 19, Art. 1.

198. CRC, supra note 18, Art. 21. This answers the suggestion that there is some kind of international right to be adopted promulgated by some adoption advocates. Many Islamic countries do not recognize adoption, using instead a system of Kafalah, which more closely resembles foster care. Maya Grosz, Provisions for Alternate Care for Children Deprived of Their Family Environment, in The U.N. Convention on the Rights of the Child: An Analysis of Treaty Provisions and Implications of U.S. Ratification 209 n.4 (Johnathan Todres et al. eds., 2006); see also Nigel Cantwell, Are Children's Rights Still Human?, in The Human Rights of Children, supra note 189, at 48-49, (commenting on the absence of a right to a family qua family in the CRC:

Implicitly distancing themselves from the human rights approach to family-related rights, many organisations (not to mention individuals) that should know better now talk blithely 
most basic requirement for those countries that do recognize or permit adoption: that it be governed by the best interests of the child standard. ${ }^{199}$

Adding the "nitty -gritty" 200 to Article 21, the Hague Convention creates a framework where each signatory State-both sending States and receiving States-creates a central authority to oversee international adoption. ${ }^{201}$ The sending State-the state of origin of the child-is responsible for establishing that the child is adoptable, ${ }^{202}$ while the receiving state-where the prospective adoptive parents habitually reside-has the responsibility to determine the eligibility and suitability of the prospective adoptive parents. ${ }^{203}$ The sending country is to ensure that all persons whose consent is necessary for adoption have been counseled and informed of the effect of their consent. The consent has to be freely given, and not induced by payments of any kind. ${ }^{204}$

\section{International Human Rights and Openness in Adoption}

International human rights instruments apply to adopted persons as well as non-adopted persons. ${ }^{205}$ In addition, as previously discussed, there are some provisions that apply specifically to adopted persons. In the $\mathrm{CRC}$, for instance, Article 21 addresses adoption. ${ }^{206}$ The Hague Convention Concerning Intercountry Adoption, as its title suggests, deals exclusively with international adoption. ${ }^{207}$ In addition, the Hague Convention, by its very terms, incorporates international human rights law. The preamble states that it intends to take into account

the principles set forth in international instruments, in particular the United Nations Convention on the Rights of the Child, of 20 November 1989, and the United Nations Declaration on Social and Legal

about a child's 'right to a family' in the sense that any child without a family must be given one ... . But neither the CRC nor any other treaty affords anything like a 'right' in this respect.

199. CRC, supra note 18, Art. 21.

200. Maravel, supra note 193, at 319.

201. Hague Convention, supra note 19, Art. 6.

202. Id. Art. 4(a).

203. Id. Art. 5(a).

204. Id. Art. 4(c) and (d).

205. Failinger, supra note 17 , at 527.

206. CRC, supra note 18, Art. 21.

207. Buck et al., supra note 178 , at $249-50$. 
Principles relating to the Protection and Welfare of Children, with Special Reference to Foster Placement and Adoption Nationally and Internationally. ${ }^{208}$ The first article also insists that international adoptions should occur "with respect for [the adopted child's] fundamental rights as recognized in international law."209

Various international human rights instruments have provisions strongly supportive of openness in international adoption. The starting point must be the venerable U.N. Universal Declaration of Human Rights ("UDHR"). Article 22 provides that "Everyone . . . is entitled to realization . . . of the economic, social and cultural rights indispensable for his dignity and the free development of his personality." ${ }^{210}$ In addition, though there is no explicit reference to identity rights, the International Covenant on Civil and Political Rights ("ICCPR") is said to protect a right to identity through its various provisions on privacy, autonomy, birth registration, citizenship, and naming. ${ }^{211}$ By emphasizing identity formation and informational rights, as well as the best interests of the child, these treaties recognize the importance of adopted persons knowing who their birth parents are and understanding their birth culture. In addition, the basic purpose to "prevent the abduction, the sale of, or traffic in children" ${ }^{12}$ encourages openness as an antidote to fraud and corruption in international adoption.

\section{Identity Rights: The Right to Know One's Parents}

The Convention on the Rights of the Child "is the first human rights treaty expressly to recognize a right to identity." ${ }^{213}$ Article 7 of

208. Hague Convention, supra note 19, Preamble.

209. Id. Art. 1.

210. Universal Declaration of Human Rights, G.A. Res. 217A (III), U.N. GAOR, 3d Sess., 1st plen. mtg., U.N. Doc A/810 (Dec. 12, 1948).

211. Samantha Besson, Enforcing the Child's Right to Know Her Origins: Contrasting Approaches Under the Convention on the Rights of the Child and the European Convention on Human Rights, 21 Int'l J.L. Pol'y \& Fam. 137, 141-42 (2007) (citing International Covenant on Civil and Political Rights, G.A. Res 2200A (XXI), U.N. Doc. A/6316, art. 17, 24 (Dec. 16, 1966)).

212. Hague Convention, supra note 19, Art. 1(b).

213. Michael Freeman, The New Birth Right: Identity and the Child of the Reproduction Revolution, 4 Int'l J. Child. Rts. 273, 283 (1996). See also Jenny Kuper, The Development of International Child Law, in Handbook of Human Rights 333, 337 (Thomas Cushman ed., 2012) (describing the addition of identity rights to the CRC as "innovative"); Besson, supra note 211, at 139 (describing how 
the CRC provides for a child's identity rights, including the right to a name, registration, and nationality at birth, and "the right to know and be cared for by his or her parents." ${ }^{14}$ As one commentator put it, these rights establish that, "[f]rom the moment of birth a child has a right to identity as a unique and unrepeatable being." ${ }^{215}$ Article 8 further focuses on identity, providing that "States Parties undertake to respect the right of the child to preserve his or her identity, including nationality, name and family relations as recognized by law without unlawful interference." ${ }^{216}$ Article 8 was proposed by Argentina, as a response to the "disappeared" during Argentina's "Dirty War," which included children of dissidents taken and put up for adoption: "Their filiation was falsified, others claiming them as their own or adopting them. In short, they were robbed of their individuality as persons and of the right to know their personal history-indeed, robbed of their rightful identity." 217 Article 8

articles 7 and 8 of the CRC expressly recognized a child's right to know her parents for the first time).

214. CRC, supra note 18, Art. 7. See also Katherine O'Donovan, "Real" Mothers for Abandoned Children, 36 Law \& Soc'y Rev. 347 (2002) Thereinafter O'Donovan, Real Mothers]. Report of the Office of the United Nations High Commissioner for Human Rights, Birth registration and the right of everyone to recognition everywhere as a person before the law, U.N. Doc. A/HRC/27/22 (June 17, 2014). This report ties birth registration to a child's acquisition of all the other rights protected by the CRC: the right to education, health care, etc. Id. IIT 17-35. The report further notes the importance of birth registration to prevent illegal adoptions:

Children without birth registration have been shown to be particularly vulnerable to exploitation in the area of illegal adoption and the sale of children. In certain countries, the illegal procurement, buying and selling of children for intercountry adoption was made possible through the falsification of documents and the production of false birth certificates. Children whose births are not registered are particularly targeted. In her recent report to the General Assembly, the Special Rapporteur on the sale of children, child prostitution and child pornography stated that children whose birth had been registered were less likely to be sold or illegally adopted, in part because they had proof of who their parents were.

Id. Il 32.

215. Cecelia P. Grosman, Argentina - Children's Rights in Family Relationships: The Gulf Between Law and Social Reality, in Children's Rights: A Comparative Perspective 7, 11 (Michael Freeman ed., 1996).

216. CRC, supra note 18, art. 8(1).

217. Grosman, supra note 215, at 16; O'Donovan, Real Mothers, supra note 214, at 352; Freeman, supra note 213, at 283. 
prohibits such practices, recognizing that "this right of every person to know his origins is a road to the truth which may not be obstructed." ${ }^{18}$ Other provisions of the CRC also implicate openness in international adoption, including Article 9, which addresses the rights of children not to be separated from their parents, ${ }^{219}$ and Article 20, which addresses the rights of children deprived of their family environment. ${ }^{220}$ Altogether, the CRC protects many aspects of the child's identity, "for example the child's personal history, its race, culture, religion, language and its physical appearance, abilities and inclinations." ${ }^{221}$ One scholar describes the identity rights protected by the CRC as incorporating the child's right "to be":

the child's right 'to be' primarily means ensuring that they will not be forced to disown their authentic familial and communal identity, to the detriment of their sense of self and of their human dignity in order to gain recognition of their normalcy by mainstream society. ${ }^{222}$

Katherine O'Donovon makes a passionate argument for the importance of identity rights and for why they are rightly considered human rights worthy of protection. Harking back to the well-known history of the removal of indigenous children from their homes, families, and communities in Australia, Canada, and the United States, she asserts that "State policies in many jurisdictions condoned-and in some places enforced-removals and lies." ${ }^{223}$ In

218. Grosman, supra note 215, at 16. Samantha Besson argues that: The right to know one's origins amounts to the right to know one's parentage, i.e., one's biological family and ascendance, and one's conditions of birth. It protects each individual's interest to identify where she comes from.

The interest to know one's origins is usually regarded as sufficiently fundamental or 'vital' to give rise to a human right. It is indeed deemed an important element in one's psychological balance to know where one comes from. Every one of us has a right to truth and hence to truth about one's origins.

Besson, supra note 211, at 140.

219. CRC, supra note 18, art. 9.

220. Id. Art. 20.

221. Besson, supra note 211, at 143-44.

222. Ya'ir Ronen, Redefining the Child's Right to Identity, 18 Int'l J.L Pol'y \& Fam. 147, 154 (2004) (internal citation omitted).

223. Katherine O'Donovan, Interpretations of Children's Identity Rights, in Revisiting Children's Rights: 10 Years of the U.N. Convention on the Rights of the Child, 73, 73-74 (Deirdre Fottrell ed., 2000) [hereinafter O'Donovan, Interpretations]; Philip Lynch, Keeping them Home: The Best Interests of 
discussing these indigenous children, and incorporating the histories of British and Irish children exported to Australia and America, she identifies the harms of this loss of identity: "Loss of roots, anger about powerlessness, shock at official betrayal of the vulnerable, loss of contact with kin, a sense of being 'different' from others, damaged emotional lives-these elements are common." ${ }^{224}$ Increased openness in international adoption can ameliorate some of these harms.

\section{a. Who are "Parents?"}

In adoption, who qualifies as "parents" for the purposes of international human rights? The practice of international adoption usually entails cutting off the parental rights of birth parents and endowing adoptive parents with those parental rights. That issue has arisen specifically under Article 7, where children are guaranteed the right to know their parents. ${ }^{225}$ After all, the "parents" referred to in Article 7 could refer exclusively to adoptive parents. Scholars argue that the right identified here is a "birth right," a right to know one's biological progenitors. ${ }^{226}$ In UNICEF's implementation handbook for the CRC, UNICEF gives an all-inclusive definition of "parent," for purposes of Articles 7 and 8 of the CRC:

[T] he definition of "parents" includes genetic parents (for medical reasons alone this knowledge is of increasing importance to the child) and birth parents, that is the mother who gave birth and the father who claimed paternity through partnership with the mother at the time of birth (or whatever the social definition of father is within the culture: the point being that such social definitions are important

Indigenous Children and Communities in Canada and Australia, 23 Sydney L. Rev. 501, 511-12 (2001); Starr \& Brilmayer, supra note 185, at 234-43.

224. O'Donovan, Interpretations, supra note 223, at 74.

225. Ineta Ziemele, A Commentary on the United Nations Convention on the Rights of the Child: Article 7, 26 (2007).

226. O'Donovan, Real Mothers, supra note 214, at 351 ("To many commentators Article 7 creates rights to know the identities of genetic parents."); Freeman, supra note 213, at 283 ("There can be few more basic rights than a right to one's identity."); O'Donovan, Interpretations, supra note 223 , at 78 ("Commentators on Article 7 take the view that it gives us the right to know the identities of genetic parents."); Besson, supra note 211, at 139:

All three conventions deal more or less expressly with the right to know one's origins, but the novelty of the $\mathrm{CRC}$, and in particular of Articles 7 and $8 \mathrm{CRC}$, was that the child's right to know her parents qua child, and not only later as an adult, was expressly recognized for the first time. 
to children in terms of their identity). In addition, a third category, the child's psychological parents-those who cared for the child for significant periods during infancy and childhood-should also logically be included since these persons too are intimately bound up in children's identity and thus their rights under article $8 .{ }^{227}$

With concern for cases of adoption, egg donation and donor insemination, several countries have entered reservations in relation to the right to know one's parents, again suggesting recognition that the "parents" spoken of in the CRC include genetic and biological parents. ${ }^{228}$ The Czech Republic expressed an intention to continue its practice of anonymous adoption and "artificial fertilization," despite the CRC provision in Article $7 .{ }^{229}$ The United Kingdom stated that it would interpret "parents" to mean "only those persons who, as a matter of national law, are treated as parents." ${ }^{230}$ Luxembourg reserved the right to maintain its "legal process in respect to anonymous births ...."231

There is also strong evidence that the Committee on the Rights of the Child, which oversees implementation of the CRC, views the word "parents" to encompass biological parents. ${ }^{232}$ In response to a report from Kazakhstan, the Committee expressed concerns that, because of the lack of a comprehensive policy regarding domestic and intercountry adoption, "adoptions are processed in such a way that seriously hinder the right of the child to know, as far as possible, her/his biological parents." ${ }^{233}$ Thus, the Committee recommended, in light of Articles 3 [best interests of the child] and 7, that Kazakhstan modify its adoption practices to allow adopted children information on

227. Rachel Hodgkin \& Peter Newell, Implementation Handbook for the Convention on the Rights of the Child 106-107 (UNICEF 2007).

228. Besson, supra note 211, at 143 .

229. Czech Republic, CRC/C/2/Rev.8, at 20, cited in Hodgkin \& Newell, supra note 227 , at 105 .

230. United Kingdom, $\mathrm{CRC} / \mathrm{C} / 2 / \mathrm{Rev} .8$, at 42 , cited in Hodgkin \& Newell, supra note 227 , at 105 .

231. Luxembourg, CRC/C/2/Rev.8, at 28, cited in Hodgkin \& Newell, supra note 227 , at 105 .

232. Ziemele, supra note 225 , at 26 .

233. Comm. on the Rights of the Child, Concluding observations: Kazakhstan, T 45, U.N. Doc. CRC/C/15/Add.213 (July 10, 2003); Ziemele, supra note 225 , at 27 . 
the identity of their parents. ${ }^{234}$ The Committee on the Rights of the Child has "objected to laws which do not allow adopted children to find out who their biological parents are." 235 Thus, the Committee chided the Russian Federation for its laws on adoption secrecy. ${ }^{236}$

The Hague Convention is less straightforward about identity rights of an adopted child and any right to know the identity of birth parents. Article 9 of the Convention does require a contracting State to "collect, preserve and exchange information about the situation of the child . . . so far as is necessary to complete the adoption." ${ }^{237}$ And Article 16 requires the sending state to "prepare a report including information about [the child's] identity, adoptability, background, social environment, family history, medical history including that of the child's family, and any special needs of the child." ${ }^{238}$ However, it seems that this is intended to be non-identifying information; Article 16 goes on to provide that when such a report is transmitted to the receiving state, the sending state shall take care "not to reveal the identity of the mother and the father if, in the State of origin, these identities may not be disclosed." 239 Nonetheless, Article 30 of the Convention requires contracting states to "ensure that information held by them concerning the child's origin, in particular information concerning the identity of his or her parents, as well as the medical history, is preserved, ${ }^{\prime 240}$ and, in so far as permitted by the law of that State, "ensure that the child or his or her representative has access to such information .... ${ }^{241}$ Indeed, under the Convention it is "recommended that receiving States and States of origin preserve adoption records in perpetuity," and should also retain "personal items relating to the child or his or her birth family." ${ }^{242}$ This

234. Comm. on the Rights of the Child, Concluding observations: Kazakhstan, If 46, U.N. Doc. CRC/C/15/Add.213 (July 10, 2003); Ziemele, supra note 225 , at 27 .

235. Ziemele, supra note 256 , at 26 .

236. Comm. on the Rights of the Child, Concluding observations: Russian Federation, IIT 40-41, U.N. Doc. CRC/C/RUS/CO/3 (Nov. 23, 2005). Similar observations were made about the adoption laws of Armenia, (Comm. on the Rights of the Child, Concluding observations: Armenia, I138, CRC/C/15/Add.225 (Feb. 26, 2004)), and Uzbekistan (Comm. on the Rights of the Child, Concluding observations: Uzbekistan, III 40-41, CRC/C/UZB/CO/2 (June 2, 2006).

237. Hague Convention, supra note 19, Art. 9(a).

238. Id. Art. 16(1)(a).

239. Id. Art. 16(2).

240. Id. Art. 30(1).

241. Id. Art. 30(2).

242. Conclusions and Recommendations and Report of the Special Comm'n . on the Practical Operation of the 1993 Hague Intercountry Adoption Convention 
information is kept because of the belief that contracting states should provide assistance to adoptees for "origin searches and reunions of the adoptees with members of their biological families."243 In 2005, the Special Commission on the practical operation of the Hague Convention discussed the balance of interests inherent in retaining and sharing information about an adopted child's birth family and concluded that it "is a lifelong experience and every piece of information could be important for the adoptee."244

Although some believe that the Hague Convention contemplates that an adoptee's identity rights are dependent on the laws of the state of origin, which may balance an adoptee's rights against a birth parent's privacy rights, ${ }^{245}$ recall that the Hague Convention explicitly incorporates the Convention on the Rights of the Child. ${ }^{246}$ And under the CRC, states are expected to modify their domestic laws to come into compliance with the CRC. Indeed, "all states parties that ratify and fully implement the provisions of the Hague Convention will meet the requirements stated in Article 21" of the Convention on the Rights of the Child. ${ }^{247}$

Adopted persons' interest in knowing birth parents are widely believed to change over time. A younger child who does not fully understand birth and adoption may not yet be at a stage where

(17-25 June 2010), II 28 (Mar. 2011) [hereinafter Special Comm'n Conclusions and Recommendations]. In 2000 , one expert "emphasised the importance of including detailed information describing the beginnings of the child's history, including for example, the exact time of the birth, the weather on that day, etc., i.e. facts which are 'precious' to the child." Permanent Bureau of the Conference, Report \& Conclusions of the Special Comm. on the Practical Operation of the Hague Convention of 29 May 1993 on Protection of Children \& Cooperation in Respect of Intercountry Adoption, II 61 (Nov. 28-Dec. 1, 2000).

243. Special Comm'n Conclusions and Recommendations 2010, supra note 242, पा 29.

244. Report and Conclusions of the Second Special Commission on the Practical Operation of the Hague Convention of 23 May 1993 on Protection of Children and Co-Operation in Respect of Intercountry Adoption (17-23 Sep. 2005) (Aug. 2006) [hereinafter Second Special Comm'n Report and Conclusions]. The report went on to say:

Countries of origin should be encouraged to collect information about birth parents, such as a photograph, or a gift to present to their children, for the future benefit of the adoptee. As more and more adoptees search for their biological families, it is important to have long-term policies and procedures for the preservation of information.

245. Id. "Not all States had the same notion of confidentiality. ..."

246. Hague Convention, supra note 19, Preamble.

247. Grosz, supra note 198, at 212. 
specific knowledge of birth parents is important to identity formation. It is often thought that it is in adolescence and young adulthood that knowledge about adoptive identity is particularly acute. The CRC certainly provides for these different stages, as the first human rights treaty to recognize the evolving capacities of children. ${ }^{248}$ Thus, even if States do not provide information that allows children at a very young age to know their parents in aid of their identity rights under Article 7, States should do so as the child matures, in light of their evolving capacities. Article 8 also imposes obligations on States to "provide appropriate assistance and protection, with a view to reestablishing speedily his or her identity." ${ }^{249}$ Thus, when an adopted person returns to the home country to search for birth parents, the State has an obligation to provide assistance.

\section{b. The Right to Know ... "as far as possible"}

Article 7 provides that a child has the right "as far as possible," to know his or her parents. ${ }^{250}$ What, precisely, is the meaning of that qualifier? The Committee has rejected secret adoption and anonymous births as justified by that qualifier, insisting instead that children have the right to know their parents. ${ }^{251}$ But what about the case of abandonment, where the State does not know the identity of the parents? In such a case, it is not possible for the child to know the parents. ${ }^{252}$ The UNICEF handbook on the CRC states bluntly, "When the child is abandoned, States Parties can do little about this." ${ }^{253}$

There is, however, a distinction between true cases of abandonment and situations in which the State facilitates or encourages abandonment. ${ }^{254}$ The Committee expressed concern about "baby flaps" or "baby nests" in Austria, where

248. CRC, supra note 18, Art. 5; Gerison Lansdown, The Evolving Capacities of the Child 3 (UNICEF Innocenti Research Center 2005); Gerison Lansdown, The Realisation of Children's Participation Rights, in A Handbook of Children and Young People's Participation: Perspectives from Theory and Practice 11, 19 (Barry Percy-Smith \& Nigel Thomas eds. 2009) (noting the need to consider evolving capacities in the best interests of the child analysis).

249. CRC, supra note 18, Art. 8(2).

250. CRC, supra note 18, Art. 7.

251. Hodgkin \& Newell, supra note 227, at 106.

252. O'Donovan, Interpretations, supra note 223 , at 78 , stating, "Clearly, contact with genetic parents is not possible if one does not know who they are."

253. Hodgkin \& Newell, supra note 227, at 106.

254. O'Donovan, Real Mothers, supra note 214, at 347. 
children are anonymously abandoned. ${ }^{255}$ Such practice is not limited to Austria-safe haven laws have proliferated in the United States, with not always positive consequences. ${ }^{256}$ In fact, there has been a worldwide proliferation of baby boxes, places of so-called "safe" abandonments. ${ }^{257}$ And though China has made child abandonment illegal, its entire system of international adoption relies on anonymous abandonment. ${ }^{258}$ The CRC requires State Parties to affirmatively change systems where abandonment is condoned. ${ }^{259}$ Abandonment is, in the language of Article 8, "where a child is illegally deprived of some or all of the elements of his or her identity." ${ }^{260}$ And under Article 8, "States Parties shall provide appropriate assistance and protection, with a view to re-establishing speedily his or her identity." ${ }^{261}$ Thus, even if the State Party is not complicit in condoning abandonment of children, the CRC imposes upon it a duty to assist in connecting the child with his or her identity.

255. Comm. on the Rights of the Child, Concluding Observations: Austria, para. 29 CRC/C/15/Add.251 (Mar. 31, 2005).

256. Evan B. Donaldson Adoption Institute, Unintended Consequences: 'Safe Haven' Laws are Causing Problems, Not Solving Them (2003); Nebraska 'safe haven' law for kids has unintended results, USA Today, Sept. 26, 2008, http://usatoday30.usatoday.com/news/health/2008-09-25-Left-kids_N.htm

(discussing the "safe haven" abandonment by a father of nine siblings, aged 1 to 17. "In all, fathers, mothers and caregivers in six families-some single parents-have bailed on 14 kids, including seven teens, since the law took effect in July." Unintended consequences, indeed, for a law designed to allow for "safe" abandonment of vulnerable newborns.).

257. China 'baby hatch' inundated with abandoned, disabled children, CNN (June 30, 2014), http://www.cnn.com/2014/06/30/world/asia/china-babyhatches-jinan/; More Foreign Babies Abandoned in Korea, The Chosunlibo (June 17, 2014), http://english.chosun.com/site/data/html_dir/2014/06/18/ 2014061801321.html (describing a "baby box" at a South Korean church that has received 400 children since 2009 ); $\mathrm{BBC}$, The 'baby box' returns to Europe, BBC (June 26, 2012), http://www.bbc.com/news/magazine-18585020 (discussing baby boxes in Germany); Saving unwanted babies, The Star Online (Malaysia) (May 30, 2010),

http://www.thestar.com.my/story.aspx/?file=\%2f $2010 \% 2 \mathrm{f5} \% 2 \mathrm{f} 30 \% 2 \mathrm{fnation} \% 2 \mathrm{f} 6369$ 239. See discussion of the medieval origins and recent revival of safe havens in O'Donovan, Interpretations, supra note 223, at 79-84.

258. Anita M. Andrew, China's Abandoned Children and Transnational Adoption, 19 J. Women's History 124 (2007).

259. See infra text accompanying notes 321-41 (discussion of obligations under the CRC).

260. CRC supra note 18, Art. 8(2).

261. Id. 
Some argue that the "as far as possible" language is not simply a restriction taking into account when a state does not know who the parents are, but a broader exception negating any argument that the right to identity is an absolute right. Professor Marianne Brower Blair argues that the legislative history of the CRC does not support an absolute right to identity information for adoptees ${ }^{262} \mathrm{Of}$ course, she concedes, as she must, that the norms of treaty interpretation give legislative history a very limited role. ${ }^{263}$ In addition, developments since her 2001 article suggest that the Committee on the Rights of the Child increasingly views the right to identity in adoption in absolutist terms. ${ }^{264}$

\section{c. The Right to Continuing Contact With Parents}

Article 9 of the CRC addresses separation of parent and child. In addition to providing that such separation should not happen against the will of the child and parent, and setting out safeguards for separation because of abuse or neglect, Article 9 also provides: "States Parties shall respect the right of the child who is separated from one or both parents to maintain personal relations and direct contact with both parents on a regular basis, except if it is contrary to the child's best interests." 65 If "parents" in Article 7 include biological parents in cases of adoption, then we must give "parents" the same meaning in Article 9. When Article 7 and 9 are taken together, the rights of the child go beyond merely knowing who one's parents are as a matter of identity, to encompass ongoing contact-what we commonly call open adoption.

Article 9 has been taken to encompass the right of children whose parents are divorced to have continuing contact with a

262. Blair, supra note 35 , at 643-49.

263. Id. at 650 , citing Vienna Convention on the Law of Treaties art. 32 , May 23, 1969, 1155 U.N.T.S. 331.

264. See infra text accompanying notes 274-276 (discussion of best interests of the child as a limitation on identity rights) and supra text accompanying notes 233-36 (discussion of Committee actions).

265. CRC, supra note 18, Art. 9(3). See also Jaap E. Doek, What Does the Children's Convention Require, 20 Emory Int'l L. Rev. 199, 203 (2006) (noting that Article 9 of the CRC also requires that "States Parties shall ensure that a child shall not be separated from his or her parents against their will, except when competent authorities ... determine ... that such separation is necessary for the best interests of the child," such as in cases of child abuse or neglect); Starr \& Brilmayer, supra note 185, at 223 (discussing the obligations on States Parties under Article 9 of the CRC that apply to the removal of children from their families). 
noncustodial parent. ${ }^{266}$ In interpreting similar provisions of the European Convention on Human Rights, jurists "are clearly of the opinion that the breakdown of an adult couple's relationship does not thereby destroy the right to family life either parent enjoys with the children of that relationship." ${ }^{267}$ The parallel to adoption is evident-adult decisions about adoptive placement should not destroy the child's right to family contact, protected by the CRC. Further, Article 9 provides for separation of parent and child initiated by the State, not just divorce actions initiated by individuals. ${ }^{268}$ In such circumstances, the State party is required to provide the parents and the child with information on the whereabouts of the absent family member, in order to facilitate contact. ${ }^{269}$ Failure to provide such information "seems to be an obvious abuse of human rights."270

Article 9 allows for a prohibition on contact when it would not be in the best interests of the child to have such contact. ${ }^{271}$ Article 21 and the Hague Convention also speak about the best interests of the child in international adoption. Article 3 of the CRC applies that standard to all actions involving children. Clearly, then, whether

266. Sharon Detric, A Commentary on the United Nations Convention on the Rights of the Child 176-78 (1999) (discussing interpretation of Article 9 with respect to maintenance of personal relations and direct contacts between children and parents who are separated).

267. Id. at 178; D. Gomein et al., Law and Practice of the European Convention on Human Rights and the European Social Charter 242 (1996).

268. CRC, supra note 18, Art. 9(4).

269. Detric, supra note 266, at 178-79; Jaap Doek, A Commentary on the United Nations Convention on the Rights of the Child: Articles 8 \& 9 (2006); Starr \& Brilmayer, supra note 185 , at 223 (noting that, where parents are separated from their children due to any action initiated by a State Party, Article 9(3) requires States to furnish the parents or children with any available information regarding their family members' whereabouts).

270. Hodgkin \& Newell, supra note 227, at 131.

271. CRC, supra note 18, Art. 9(3) ("States Parties shall respect the right of the child who is separated from one or both parents to maintain personal relations and direct contact with both parents on a regular basis, except if it is contrary to the child's best interests."). See also John Eekelaar, The Interests of the Child and the Child's Wishes: The Role of Dynamic Self-Determinism, in The Best Interests of the Child 48-49 (Philip Alston ed., 1994) (discussing the growing belief that children should, where possible, maintain contact with the absent parent after separation); Hodgkin \& Newell, supra note 227, at 131 (arguing for a "presumption ... that children will be more damaged by ignorance of their parents' whereabouts ... than by the discovery of the absent family member's fate ...."). 
openness in international adoption is required is determined, at least in part, by whether it is in the best interests of the child. ${ }^{272}$

\section{Best Interests of the Child}

Both the Hague Convention and Article 21 of the Convention on the Rights of the Child require that adoptions be done only in the best interests of the child. Article 3 of the CRC provides further support for this requirement, providing that in all actions concerning children, "[T]he best interests of the child shall be a primary consideration." 273 There is debate about whether the best interests of the child standard applies to identity rights in the CRC. One can argue that any balancing would violate the right to know; after all, there are only two possibilities-knowing and not knowing. Not knowing violates the right to know, regardless of the reason. As is more elegantly expressed by Samantha Besson, "balancing the right to know might lead to violating the inner core ('noyau fondamental' or 'Kerngehalt') of the right and hence it becomes devoid of any content." ${ }^{274}$ Further, it is important to note that Article 7 already has a specific limitation-that the right to know applies only "as far as possible." This much stricter limitation appears to trump the best interests of the child test of Article $3{ }^{275}$ Even if the best interests standard applies to Article 7, best interests would mandate openness.

'Best interests of the child' is one of the most familiar concepts in international law, but there is no talismanic definition. ${ }^{276}$ Nonetheless, "the principle has come to be known in one form or another to many national legal systems and has important analogues

272. Article 7 does not have any best interests of the child limitation, raising questions about whether identity rights are subject to best interests of the child analysis. CRC, supra note 18, Art. 7 .

273. Id. Art. 3(1).

274. Besson, supra note 211, at 148. Besson further states, "based on a holistic approach to the Convention, one may even regard Articles 7 and $8 \mathrm{CRC}$ as giving a clear and absolute priority to the interests of the child over those of her parents...." Id. at 149 .

275. Id. at 147 (noting that, "Article $7 \mathrm{CRC}$ appears to provide much stricter guidelines and be less subjective than Article 3 . Thus, short-term considerations pertaining to the child's welfare should not take priority over her objective moral interests").

276. Philip Alston, The Best Interests Principle: Towards a Reconciliation of Culture and Human Rights in The Best Interests of the Child 3-4 (1994) (noting the use of the phrase "best interests of the child" in various international instruments, but concluding that "the principle ... has yet to acquire much specific content or to be the subject of any sustained analysis designed to shed light on its precise meaning."). 
in diverse cultural, religious and other traditions."277 'Best interests' is not defined in the Conventions, ${ }^{278}$ but the predecessor document, the 1959 Declaration of the Rights of the Child, gives some guidance:

The child shall enjoy special protection, and shall be given opportunities and facilities, by law and by other means, to enable him to develop physically, mentally, morally, spiritually and socially in a healthy and normal manner and in conditions of freedom and dignity. In the enactment of laws for this purpose, the best interests of the child shall be the paramount consideration. $^{279}$

One scholar simplifies the definition as follows: Basic interests, for example to physical, emotional and intellectual care; developmental interests, to enter adulthood as far as possible without disadvantage; and autonomy interests, especially the freedom to choose a lifestyle of their own. ${ }^{280}$

There are obviously cultural differences in the understanding of the best interests of the child-Alston posits different understandings in industrialized societies and in more traditional societies as an example. ${ }^{281}$ The goal of the CRC was to set universal standards in the field of human rights. ${ }^{282}$ In response to criticisms of

277. Id. at $4-5$.

278. Id. at 11 ("[T]he drafters of Article 3(1) appear to have been sufficiently familiar with the phrase 'the best interests of the child' from its extensive usage in the domestic law of many countries as to conclude that that it required no close analysis.").

279. Declaration of the Rights of the Child, G.A. Res. 1386 (XIV), 14 U.N. GAOR Supp. No. 16 (at 19), U.N. Doc. A/4354, Principle 2 (Nov. 20, 1959). Similar language appeared in the first draft of the CRC, but it was deleted in a battle over whether the best interests of the child should be the singular consideration of one of many considerations when taking actions affecting children. Alston, supra note 276; Eekelaar, The Interests of the Child and the Child's Wishes, supra note 271, at 10 .

280. John Eekelaar, The Importance of Thinking that Children Have Rights, 6 Int'l J.L. \& Fam. 221, 231 (1992).

281. Alston, supra note 276; The Best Interests of the Child, supra note 271 , at 1 (noting that in highly industrialized countries, "best interests" may be seen as promoting a child's autonomy and individuality, while in more traditional cultures "best interests" might be seen as those that promote the child's role as connected to the family and community).

282. Id. (the CRC represents "the culmination of half a century of international efforts to set 'universal' standards in the field of human rights."). But see Abdullah An-Na'im, Cultural Transformation and Normative Consensus on the Best Interests of the Child, 8 Int'l J.L. \& Fam. 62, 63 (1994) (noting that the CRC in general may represent "much apparent consensus on very little substance"). 
the indeterminacy and Western-centric focus of the best interests of the child standard, Alston suggests that the CRC itself, adopted by all but two nations, provides a "broad ethical or value framework that is often claimed to be the missing ingredient which would give a greater degree of certainty to the content of the best interests principle." ${ }^{283}$ Thus, the CRC (and the Hague Convention) provides universally accepted signposts for the values to be considered in the best interests of any particular child.

The best interests of the child standard would, in most cases, require recognition of the rights of identity, the right to know and keep contact with birth parents, outlined in Articles 7, 8, and 9 of the $\mathrm{CRC}$ and in the Hague Convention's various provisions requiring sending countries to maintain and share information about birth parents. ${ }^{284}$ These universally accepted signposts recognize what empirical studies have confirmed: this information is crucial in adoptees' ongoing process of identity formation. ${ }^{285}$

Another ethical and value-laden signpost in the CRC that informs the best interests of the child standard is its anti-discrimination provision. Article 2 states:

States Parties shall respect and ensure the rights set forth in the present Convention to each child within their jurisdiction without discrimination of any kind, irrespective of the child's or his or her parent's or legal guardian's race, colour, sex, language, religion, political or other opinion, national, ethnic or social origin, property, disability, birth or other status. ${ }^{286}$

Scholars have argued that this anti-discrimination policy is violated by closed international adoption because adopted children are denied the right to know their biological kin, while other children, not relinquished for adoption in the sending country, are allowed to

283. Alston, supra note 276, Eekelaar, The Interests of the Child and the Child's Wishes, supra note 271, at 19; Eekelaar, supra note 280, at 231-32.

284. See supra text accompanying notes 213-71. See also Eekelaar, supra note 280, at 231-32 (noting the primacy of identity rights). Eekelaar makes the case for identity rights powerfully in the context of artificial insemination:

[T] he concealment from a child of information about its birth by artificial insemination is usually justified on the ground that this is in the child's best interests. But the rights perspective poses the question: would that child, as an adult, be likely to choose to live his or her life on the basis of a deliberate deception about his or her origins?

Id. at 230.

285. See supra text accompanying notes 151-74.

286. CRC, supra note 18, Art. 2(1). 
know theirs. ${ }^{287}$ Discrimination based on a child's adoptive status, denying that child's identity rights, violates that child's best interests.

The CRC provides for a right to health care for children, which also implicates identity rights. Without knowledge of biological roots, that right to health care can be negatively affected. ${ }^{288}$

Those who argue for secrecy in adoption generally do so based on the interests of others, not the child. For example, it is often posited that an unwed birth mother is so stigmatized by an out-ofwedlock birth that her privacy must be maintained when she relinquishes a child for adoption. ${ }^{289}$ While the stigma of unwed motherhood has lessened in some parts of the world, where we find that open adoption actually benefits birth mothers, ${ }^{290}$ it has not lessened in other parts of the world-and those parts tend to be the sending countries in international adoption. Professor Frances Olsen, in a powerful argument against openness in adoption in some circumstances, says, "as long as many societies in the world seriously penalize unmarried women who give birth to a child, there is some question whether a woman should not be entitled to maintain her anonymity when she gives a child up for adoption."291

Of course, this presents something of a chicken-or-the-egg problem-so long as unwed birth mothers maintain anonymity, they are invisible, and there is little possibility to lift the stigma associated with unwed births. Secrecy allows us to "other" birth mothers and thereby deny their humanity. This argument also assumes that birth mothers in international adoption are all unwed mothers, which is not at all the case, ${ }^{292}$ and that all unwed mothers value their

287. Leslie Doty Hollingsworth, International Adoption among Families in the United States: Considerations of Social Justice, 48 Social Work 209, 212 (2003). See also Besson, supra note 211, at 140 ("adopted or AI children, who depend on the goodwill of authorities or their social parents to know about their origins, suffer from discrimination by comparison to children whose social and genetic parents match.").

288. Id. (noting that identity rights include an "interest to know one's medical history.").

289. Frances Olsen, Children's Rights: Some Feminist Approaches to the United Nations Convention on the Rights of the Child, 6 Int'l J.L. \& Fam. 192 (1992).

290. See supra text accompanying notes 109-16.

291. Olsen, supra note 289 , at 201 .

292. As one author succinctly put it, "not all unwed mothers are birth mothers, nor are all birth mothers unmarried." Kim, supra note 5, at 131-32. Kim further notes, "The emphasis on single unwed mothers neglects the significant 
anonymity over any contact with their children relinquished for adoption. ${ }^{293}$ Further in the more than twenty years since Olsen wrote, in some sending countries, there have already been successful efforts to de-stigmatize unwed births and support single parenthood. In Korea, for instance, advocacy from unwed mothers, adult adoptees, and other activists has resulted in legislation that is more supportive of parenting by unwed mothers. There is also a difference between allowing adoptees to know who their biological parents are and the kind of loss of privacy that some fear will inure to the detriment of birth mothers. Contact can be made in ways that still protect the privacy of the birth mother, as has been well established in countries with open adoption records. ${ }^{294}$

These claims about privacy for women and concerns about conflicts between mothers and children created by the CRC are worthy of serious consideration. Of course, given the abundance of human rights which protect fundamental interests, "conflicts of human rights are common." ${ }^{295}$ Many such conflicts are resolved as a right is recognized, through the delineation of the scope of the right. ${ }^{296}$ One might argue that the CRC has resolved the potential conflict between birth family and their adopted-out children by announcing the primacy of the best interests of the child. Indeed, in adoption the best interests of the child are the paramount consideration, not just $a$ consideration to be balanced against the interests of others. This focus on the best interests of the child in the

number of women in common-law or legal marriages who gave up their children for adoption because of extreme poverty." Id. at 141 .

293. Birth mothers in international adoption often search for their relinquished children. See $A$ Letter to Sang-Ah, http://searchingformydaughter.weebly.com/ (where a Korean birth mother is seeking her daughter adopted to France in 1979).

294. Some states in the United States with open records, as well as in other countries with open records, provide a "no contact" proviso, so that when adoptees access their records, they know that their birth mother is not open to contact. Samuels, supra note 27, at 60-61. "But the right of adopted children to information did not have to infringe the biological parents' right to privacy. Information would not be made public, but only supplied to the adopted child." Guide to Good Practice Under the Hague Convention of 29 May 1993 on Protection of Children and Co-Operation in Respect of Intercountry Adoption, 2 Hague Conference on Private Int'l Law, at 17-23 (Sept. 2005). One author suggests that international searchers hire a local professional searcher: "Professionals know whom to talk to and where to look. They know the customs and speak the language, and can make contact in a sensitive and discreet way." Brown, supra note 13.

295. Besson, supra note 211, at 146.

296. Id. 
CRC is quite deliberate, a choice to elevate the interests and rights of children. Yes, the Convention does grant parents (and perhaps other adults in their stead) the right to make decisions for children too young to do so for themselves. But this must be done in protection of the rights granted by the CRC, not in derogation of those rights. ${ }^{297}$ "[N]either the 'responsible' adults, nor the State itself in pursuance of its duty under Article $3 \ldots$ can cut down on the substance of the specific rights insofar as such rights are delineated in the Convention." ${ }^{298}$ This is what it means to take children's rights seriously. ${ }^{299}$

\section{Preventing Corruption and Trafficking}

One of the primary purposes of the Hague Convention, and Article 21 of the CRC, is to prevent corruption in international adoptions. Article 21 of the CRC commands that States Parties shall "[t]ake all appropriate measures to ensure that, in inter-country adoption, the placement does not result in improper financial gain for those involved in it." ${ }^{300}$ The preamble of the Hague Convention explains the necessity of the Convention "to prevent the abduction, the sale of, or traffic in children." ${ }^{301}$ The Convention lists as one of its three objects, "to establish a system of co-operation amongst Contracting States ... and thereby prevent the abduction, the sale of, or traffic in children." ${ }^{302}$ The Convention expounds on this objective in further provisions, ensuring that "the consents [to adoption] have not been induced by payment or compensation of any kind," ${ }^{303}$ that states "shall take, directly or through public authorities, all appropriate measures to prevent improper financial or other gain in connection with an adoption," 304 that "no one shall derive improper financial or other gain from an activity related to an intercountry adoption," ${ }^{305}$ that "only costs and expenses, including reasonable professional fees of persons involved in the adoption, may be charged or paid," ${ }^{306}$ and

297. Eekelaar, supra note 280, at 233.

298. Id.

299. Id.

300. CRC, supra note 18, Art. 21(d).

301. Hague Convention, supra note 19, pmbl.

302. Id. Art. 1.

303. Id. Art. 4(c)(3). See also Hague Convention, Art. 4(d)(4) (where a child's consent is required to the adoption, that consent cannot be "induced by payment or compensation of any kind.").

304. Id. Art. 8.

305. Id. Art. 32(1).

306. Id. Art. 32(2). 
that "directors, administrators and employees of bodies involved in an adoption shall not receive remuneration which is unreasonably high in relation to services rendered." 307 UNICEF's statement concerning intercountry adoption emphasizes the problem of corruption:

Over the past 30 years, the number of families from wealthy countries wanting to adopt children from other countries has grown substantially. At the same time, lack of regulation and oversight, particularly in the countries of origin, coupled with the potential for financial gain, has spurred the growth of an industry around adoption, where profit, rather than the best interests of children, takes centre stage. Abuses include the sale and abduction of children, coercion of parents, and bribery. ${ }^{308}$

Virtually every sending country-Cambodia, ${ }^{309}$ China, ${ }^{310}$ Ethiopia, ${ }^{311}$ Guatemala, ${ }^{312}$ and Vietnam, ${ }^{313}$ to name a few-has been

307. Id. Art. 32(3).

308. UNICEF, UNICEF's Position on Inter-Country Adoption (Oct. 4, 2007), available at http://www.unicef.org/malaysia/media_unicef-positionintercountry-adoption.html.

309. Karen Smith Rotabi, Fraud in Intercountry Adoption: Child Sales and Abduction in Vietnam, Cambodia, and Guatemala, in Intercountry Adoption: Policies, Practices, and Outcomes 67, 70 (Judith L. Gibbons \& Karen Smith Rotabi eds., 2012); Trish Maskew, Child Trafficking and Intercountry Adoption: The Cambodian Experience, 35 Cumb. L. Rev. 619, 621 (2005). The scandal in Cambodia led to the criminal conviction of two American adoption agency employees, sisters Lauryn Galindo and Lynn Devin. Press Release, Dep't of Justice (June 23, 2004), available at http://www.justice.gov/opa pr/2004/June/04_crm_434.htm.

310. David M. Smolin, The Missing Girls of China: Population, Policy, Culture, Gender, Abortion, Abandonment and Adoption in East-Asian Perspective, 41 Cumb. L. Rev. 1, 59-61 (2011); Patricia J. Meier \& Xiaole Zhang, Sold Into Adoption: The Hunan Baby Trafficking Scandal Exposes Vulnerabilities in Chinese Adoptions to the United States, 39 Cumb. L. Rev. 87 (2008); Shangguan Jiaoming, In Hunan, Family Planning Turns to Plunder, Caixin Century Magazine (May 10, 2011), available at http://english.caixin.com/2011-0510/100257756.html.

311. Kathryn Joyce and Michael Tsegaye, "Child Harvesting" in Ethiopia's Adoption Program, Pulitzer Center (Jan. 5, 2012), http://pulitzercenter.org/ reporting/ethiopia-internationa-adoption-program-child-harvesting-fraud-

corruption-trafficking; Kathryn Joyce, Adoption Inc: How Ethiopia's Industry Dupes Families and Bullies Activists, Pulitzer Center (Dec. 21, 2011), http://pulitzercenter.org/reporting/ethiopia-international-adoption-program-

ethics-birth-families-activists. In 2014, four current and former employees of an American adoption agency were indicted by a grand jury in South Carolina for allegedly conspiring to defraud the United States in connection with adoption 
rocked with scandals relating to baby buying, kidnapping, bribery and coercion of birth parents. Professor David Smolin has documented the practice of "child laundering"-where children's adoptable status is falsified in their "legal" documentation, masking any corruption or coercion that brought them into the international adoption process. ${ }^{314}$ This is a particularly insidious part of child trafficking into adoption, because it calls into question all supposedly legal paperwork in the sending country relating to the adoption. It makes it impossible for adoptive parents and government officials to have any confidence that corruption and coercion did not occur in any adoption, and allows "apologists for international adoption," in Professor Smolin's terms, to argue that there is very little documented corruption. ${ }^{315}$

International adoptive parents have searched for birth parents because of concerns that the child they adopted was

services in Ethiopia. Press Release, U.S. Dep't of Justice (Feb. 11, 2014), available at http://www.justice.gov/opa/pr/2014/February/14-crm-149.html.

312. Kelley McCreery Bunkers \& Victor Groza, Intercountry Adoption and Child Welfare in Guatemala: Lessons Learned Pre-and Post-Ratification of the 1993 Hague Convention on the Protection of Children and Cooperation in Respect of Intercountry Adoption, in Intercountry Adoption, supra note 309, at 121; Dubinsky, supra note 178, at 109-22; Rotabi, supra note 309, at 74; U.N. Comm'n on Human Rights, Report of the Special Rapporteur on the Sale of Children, Child Prostitution and Child Pornography, II 13, E/CN.4/2000/73/Add.2 (Jan. 27, 2000).

313. Rotabi, supra note 309 , at 70 ; Sixteen on trial for selling babies for adoption, The Independent (Sept. 23, 2009), http://www.independent.co.uk/ news/world/asia/16-on-trial-for-selling-babies-for-adoption-1791716.html.

314. David M. Smolin, Child Laundering: How the Intercountry Adoption System Legitimizes and Incentivizes the Practices of Buying, Trafficking, Kidnapping, and Stealing Children, 52 Wayne L. Rev. 113 (2006); Smolin, supra note 177 , at 1.

315. David M. Smolin, The Two Faces of Intercountry Adoption: The Significance of the Indian Adoption Scandals, 35 Seton Hall L. Rev. 403, 451 (2005). Professor Elizabeth Bartholet qualifies as one of Professor Smolin's "international adoption apologists," as she frequently argues that there is no evidence of systemic adoption corruption. See, e.g., Elizabeth Bartholet, International Adoption: The Human Rights Position, 1 Global Policy 91, 96 (2010) ("Adoption abuses exist, as abuses exist in every area. But there is no persuasive evidence that adoption abuses are extensive."); Elizabeth Bartholet \& David Smolin, The Debate, in Intercountry Adoption, supra note 309, at 377 (Elizabeth Bartholet: "there is no persuasive evidence that such abuses are widespread; instead, they seem a very small part of the total international adoption picture, with the overwhelming majority of adoptions taking place in compliance with the law."). 
trafficked and the birth parents coerced. ${ }^{316}$ In some cases, that birth parent contact revealed corruption. ${ }^{317}$ In other cases, concerns about trafficking and coercion were alleviated. ${ }^{318}$ If birth parent contact were the norm in international adoption, that level of transparency would mitigate against corruption and coercion. Those agencies and orphanage directors and adoption facilitators who are motivated to procure children from birth parents illegally would find their practices more difficult if birth parents were required to be involved in the process. As Justice Louis D. Brandeis put it, "Publicity is justly commended as a remedy for social and industrial diseases. Sunlight is said to be the best of disinfectants; electric light the most efficient policeman." 319

The CRC's insistence on the child's right to know his or her parents and the Hague Convention's requirement that sending countries document information about the child's birth parents can be seen as going beyond identity and informational rights. These provisions also help to combat the kind of corruption sometimes found in international adoption.

\section{FACILITATING OPENNESS IN INTERNATIONAL ADOPTION}

Although the CRC is clear on the rights of the child to openness in international adoption, the way forward to enforcing those rights is considerably more opaque. There is no general personal right to petition under the $\mathrm{CRC},{ }^{320}$ although a new optional protocol allows such complaints in the few states that have signed and ratified the optional protocol. ${ }^{321}$ The CRC imposes obligations on

316. Howard, supra note 14 (family institutes search after learning Guatemalan attorney who had facilitated the adoption of their child in Guatemala had been arrested on corruption charges).

317. An Adoption Gone Wrong, NPR (July 24, 2007), http://www.npr.org/ 2007/07/24/12185524/an-adoption-gone-wrong (interviewing Desiree and David Smolin (adoption scholar) about their discovery that their internationally adopted children were not orphans, but had been stolen from their mother).

318. Larson, supra note 14.

319. Louis D. Brandeis, Other People's Money - And How the Bankers Use It 92 (1914) (discussing the role of publicity in combatting industrial and social disease).

320. A. Glenn Mower, Jr., The Convention on the Rights of the Child: International Law Support for Children 97 (1997).

321. Optional Protocol to the Convention on the Rights of the Child on a Communications Procedure, G.A. Res. 66/138, Art. 10, II 5, U.N. Doc. A/RES/66/138 (Jan. 27, 2012), entered into force April 14, 2014 Thereinafter OP3CRC]. The optional protocol has been ratified by Albania, Belgium, Bolivia, Costa 
States Parties to bring their laws and policies in line with the Convention, however, and States Parties have agreed to do so "by adhering to an instrument that contains legally binding commitments." 322

The Convention is said to contain both negative rights and positive rights. Negative rights are those that protect one's interests against active violations by the State. ${ }^{323}$ Positive rights are those that impose obligations on the state to act, that protect against the state's failure to act. ${ }^{324}$ Are identity rights positive or negative rights? Samantha Besson argues that they are both:

The right to know one's origins is usually guaranteed as a negative right that protects one's interests against active violations by state authorities, but also-and that is most important given the importance of registering, preserving and opening access to birth data-as a positive right that protects against a passive omission of the state. ${ }^{325}$

So, sending countries in international adoption have positive obligations to ensure that children placed for adoption have

Rica, Gabon, Germany, Montenegro, Portugal, Slovakia, Spain, and Thailand. G.A. Res. 66/138, Art. 10, I. 5, U.N. Doc. A/RES/66/138 (Jan. 27, 2012). See Status of Ratification Tbl., available at https://treaties.un.org/Pages/ViewDetails.aspx? src=TREATY\&mtdsg_no=TV-11-d\&chapter=4\&lang=en. As one scholar describes, the optional protocol is relatively non-interventionist, with provisions:

to simply allow an individual child to submit a complaint to the

Committee on the Rights of the Child alleging specific violations of their rights under the Convention or its first two optional protocols. The Committee would then examine the child's complaint and, in response, could merely request that the child's government take actions to prevent any further damage to the complainant.

Howard Davidson, Does the U.N. Convention on the Rights of the Child Make a Difference?, 22 Mich. St. Int'1 L. Rev. 498, 510 (2013) (emphasis in original).

322. Mower, supra note 320 , at 61 .

323. Stephen P. Marks, Emerging Human Rights: A New Generation for the 1980s?, 33 Rutgers L. Rev. 435, 438 (1980-81) (describing positive rights as "freedom from" state interference); Elizabeth M. Iglesias, Foreword: International Law, Human Rights, and LatCrit Theory, 28 U. Miami Inter-Am. L. Rev. 177, 183 n.6 (1996-97); Todd Landman, Measuring Human Rights: Principle, Practice, and Policy, 26 Hum. Rts. Q. 906, 922-23 (2004).

324. Marks, supra note 323 , at 435 (describing positive human rights as "characterized by the intervention rather than the abstention of the state"). See also Joel E. Oestreich, UNICEF and the Implementation of the Convention on the Rights of the Child, 4 Global Governance 183, 187 (1998) ("Positive rights, on the other hand, go further, requiring positive action by others.").

325. Besson, supra note 211 , at 145. 
information about their origins, including the names of birth parents. ${ }^{326}$ Sending countries also have the obligation to facilitate ongoing contact between adopted children and their birth parents. ${ }^{327}$ In countries that permit or encourage abandonment of children, states have a positive obligation to prevent such abandonments so that children do have the ability to know their parents, crucial to their identity rights. ${ }^{328}$ Thus, State Parties to the CRC need to pass legislation and enact policies mandating such openness in international adoption.

The CRC imposes reporting obligations on States Parties to show how they are in compliance with the Convention, ${ }^{329}$ provides for review of those reports by the Committee on the Rights of the Child, ${ }^{330}$ and allows non-governmental organizations to report to the Committee on issues of non-compliance by States Parties. ${ }^{331}$ With no other enforcement mechanism, the CRC is considered a "soft" international human rights treaty. ${ }^{332}$ Nonetheless, there are ways to facilitate openness in international adoption through the CRC and the Hague Convention.

First, the Committee on the Rights of the Child can accomplish much through the monitoring process. As Professor Jonathan Todres notes, there is skepticism about the effectiveness of monitoring regimes in international human rights treaties, given the lack of sanctions for failing to abide by treaty terms. ${ }^{333} \mathrm{He}$ explains the value as lying in the process itself:

Those arguments ignore the fact that international law, particularly human rights law, is enforced differently from domestic law; among the various enforcement mechanisms, public scrutiny before the

326. See supra text accompanying notes 213-49.

327. See supra text accompanying notes $265-72$.

328. See supra text accompanying notes 250-61.

329. Doek, supra note 269, in The Human Rights of Children, supra note 189 , at $101-02$.

330. Id. at 102-03.

331. Jonathan Todres, A Child Rights Framework for Addressing Trafficking of Children, 22 Mich. St. Int'1 L. Rev. 557, 574, 576 (2013) ("The alternative reports and pre-session working group meetings ensure that NGOs play a meaningful role in the review process.").

332. Davidson, supra note 321, at 511-12. "Soft law" can, nonetheless, be powerful law. As Davidson notes, “[d]espite lacking 'enforcement teeth,' soft law can be very powerful when it comes to encouraging actions by governments to better protect vulnerable populations. It has incredible norm-creating value." Id. at 512 .

333. Todres, supra note 331 , at 574 . 
international community compels many governments to follow the mandate of human rights law. The reporting process plays a key role in advancing countries' efforts to ensure the rights of individuals subject to their jurisdiction. Moreover, a reporting process centered on children, as the CRC's reporting process is, ensures that governments are focused sufficiently on children's needs and are progressing toward ensuring the rights and well-being of all children. ${ }^{334}$

Jaap Doek describes the monitoring process as a dynamic one, often spurring countries to speed up the implementation of legislation or policies to bring the country into compliance before it has to report to the committee:

It is remarkable how often States Parties report-sometimes in response to a list of issues-that they have recently enacted new provisions or developed a new plan of action for, for example, the prevention of violence against children, and the trafficking and/or sexual exploitation of children. This is an interesting and welcome dynamic element in the reporting process. ${ }^{335}$

During the monitoring process, the Committee can focus the attention of States Parties on specific issues on which it is to report, thereby prodding for changes prior to a response. ${ }^{336}$ The Committee then reviews the country's submission so that it can "present to the State Party concerned targeted and concrete recommendations for further actions in the so-called Concluding Observations." ${ }^{337}$

Second, the Committee is more than simply a monitoring body. It has the power, under the CRC, to foster implementation of the rights of the child enshrined in the CRC. ${ }^{338}$ Further, the

334. Id. at 574-75.

335. Doek, supra note 269, in The Human Rights of Children, supra note 189 , at 102; see also Todres, supra note 331, at 577-78 (noting that the process is a collaborative, non-adversarial one, "a dialogue between the Committee and the government.").

336. Doek, supra note 269, in The Human Rights of Children, supra note 189 , at 102 .

337. Id. at 102-03; Todres, supra note 331, at 575.

338. CRC, supra note 18, Art. 45; Doek, supra note 269, in The Human Rights of Children, supra note 180 , at 100; Mower, supra note 320 , at 96 (noting "the role of the Committee is not only to evaluate the efforts made by States to fulfill their obligations under the convention, but also to help them, when 
Committee has the obligation to seek technical assistance for States that need and request it. ${ }^{339}$ The Committee, through this "fostering" power, has commissioned United Nations studies on important aspects of the $\mathrm{CRC},{ }^{340}$ and it has issued numerous "General Comments" to promulgate its interpretation of provisions of the CRC. ${ }^{341}$

Some actions that the Committee and others-including NGOs and individuals-should take to facilitate openness in international adoption include the following:

\section{A. Host a Day of Discussion on the Topic of Identity Rights in Adoption}

Days of General Discussion are organized annually by the Committee and have spurred positive action, such as published General Comments, U.N. studies, and the appointment of Special Representatives on discrete topics by the Secretary-General of the U.N. ${ }^{342}$ This kind of special attention is desperately needed on the topic of children's identity rights, especially in the context of adoption and assisted reproductive technology.

\section{B. Issue General Comments on Identity Rights in Adoption}

General Comments have become an important traditional part of human rights treaty bodies. ${ }^{343}$ The CRC Committee has issued seventeen General Comments on various topics, such as the aims of education, implementing the rights of children in early childhood, the rights of children with disabilities, and the rights of the child to have his or her best interests considered. ${ }^{344}$ These General Comments

appropriate, to obtain assistance needed to overcome obstacles to full implementation.").

339. CRC, supra note 18, Art. 45(b); Mower, supra note 320, at 96 . Mower notes: "This involvement of the committee in technical assistance, as one observer has noted, constitutes 'a change in the very concept of a treaty monitoring body." Mower, supra note 320, at 96.

340. Doek, supra note 269, in The Human Rights of Children, supra note 189 , at 105 .

341. Id. There have been 17 such General Comments to date.

342. Id. at 104-05.

343. Id. at 105.

344. These comments are all available on the website of the U.N. Human Rights Commission. Office of the High Commissioner for Human Rights, United Nations Human Rights, http://www.ohchr.org/EN/HRBodies/CRC/Pages/ CRCIndex.aspx (follow link to "General Comments" on the left hand column under "The work of the Committee") (last visited Feb. 23, 2015). 
announce the Committee's interpretations of the CRC, which then guide States Parties in implementing the CRC and also guide the Committee in evaluating compliance. ${ }^{345}$ By issuing a General Comment on identity rights of children, including identity rights of adopted children, the Committee can foster those rights by state actors.

\section{Encourage More Research on Open Adoption in the} International Context

The Committee has recognized the importance of "[c]ollection of sufficient and reliable data on children, disaggregated to enable identification of discrimination and/or disparities in the realization of rights," to the implementation of the CRC. ${ }^{346}$ The Committee further notes the need for States and research institutes to collaborate on qualitative and quantitative research to examine progress toward implementation of the rights of children protected under the CRC. ${ }^{347}$ As one scholar describes it, the CRC has produced "the principle that children have the right to be properly researched." ${ }^{348}$ The paucity of research on openness in international adoption is a serious impediment to the implementation of the CRC's identity rights provisions. The Committee, NGOs, adoption agencies and organizations, and others need to solicit more research on the topic.

\section{Promulgate More Widely-And in Particular, in Sending Countries-Information About the Positive Effects of Open Adoption in those Countries Where it is Widely Practiced}

While there has been very little research on openness in international adoption, there is a robust body of work on openness in adoption in the U.S. and other Western countries. ${ }^{349}$ That research needs to be disseminated more widely, especially in sending countries in international adoption. Regional follow-up meetings might serve as

345. Doek, supra note 269, in The Human Rights of Children, supra note 189, at 105.

346. Committee on the Rights of the Child, General Comment No. 5, General Measures of Implementation of the Convention on the Rights of the Child II 48, CRC/GC/2003/5 (Nov. 27, 2003) [hereinafter General Comment No. 5].

347. Id.

348. Harriot Beazley, et al., How are the Human Rights of Children Related to Research Methodology?, in The Human Rights of Children, supra note 189, at 161.

349. See supra text accompanying notes 86-117. 
an appropriate forum. ${ }^{350}$ While cultures differ, sending countries cannot know whether positive results of openness would apply to their circumstances until and unless the research is available to them. The availability of that information can then spur studies in their particular culture to see if the benefits are replicable there. The available research may convince sending countries that they really can respect the identity rights of the child of adoption.

\section{E. Offer Technical Assistance to Countries to Convert their Systems of Adoption to Open Adoption}

The Committee can facilitate technical assistance to countries that request it and requesting technical assistance can occur during the dynamic monitoring process. ${ }^{351}$ For most countries, it will take little to convert to open adoption. Countries like China, which relies on condoned abandonment, might require technical assistance to develop a system that relies on voluntary relinquishment instead. With state involvement in voluntary relinquishment instead of secret abandonment, the child's right to know his or her parents can be fostered.

F. Ask NGOs to Audit the Laws and Policies of Sending Countries to Facilitate Reporting on What Changes Need to be Made to Ensure Identity Rights in Adoption

Although the CRC is monitored based on self-reporting by States Parties, it is not purely a passive process for the Committee. The Committee can acquire information about a state's compliance with the CRC through other independent sources, including "parliamentary committees, NGOs, academic institutions, professional associations, youth groups and independent human rights institutions."'352 "In practice, the Committee has 'systematically and strongly encouraged NGOs to submit reports, documents or other

350. Doek, supra note 269, in The Human Rights of Children, supra note 189 , at 104.

351. UNICEF is typically the body to which such requests for technical assistance are forwarded. Oestreich, supra note 324, at 185. See also Mower, supra note 320 , at 96 (noting the significance of the Committee's role in soliciting technical assistance).

352. Kilkelly, supra note 189, at 185 (citing General Comment No. 5, supra note 346, II 46); Todres, supra note 331 , at 574 (noting that "NGOs play a meaningful role in the review process."); Gamze Erdem Turkelli \& Wouter Vandenhole, The Convention on the Rights of the Child: Repertoires of NGO Participation, 12 Hum. Rts. L. Rev. 33, 34. (2012). 
information in order to provide it with a comprehensive picture and expertise as to how the Convention is being implemented in a particular country." ${ }^{353}$ Rather than waiting passively for states to report on their laws and policies regarding openness in international adoption, the Committee must request such information in order to foster children's identity rights in adoption.

\section{G. Individuals and Groups Should Bring Strategic Litigation to Seek Enforcement of the Identity Rights in the CRC}

"There is no Court of the Rights of the Child." ${ }^{354}$ Nonetheless, Ursula Kilkelly has argued that strategic national and international lawsuits based on the CRC can benefit individual children and also "have a broader positive effect on the lives of a greater number of children. ${ }^{355}$ Even in jurisdictions like the United States, which has not signed or ratified the CRC, or Canada, where the CRC has not been made part of domestic law, the CRC can have a strong advisory effect because of the authority it enjoys due to its rapid acceptance in the international community as setting norms for the treatment of children. ${ }^{356}$ National litigation by adoptees in courts of sending countries, especially those that have signed and ratified the CRC, seeking their identity rights, may be fruitful. Bringing such lawsuits may also serve as a necessary prerequisite to bringing complaints directly to the Committee under the new optional protocol on communications procedures, which requires exhaustion of domestic remedies. ${ }^{357}$

\section{H. Individuals and Groups Affected by Closed International} Adoptions Should Utilize the Optional Protocol on Communications Procedures to Bring Complaints Directly to the Committee

There has been little precedent for utilizing the optional protocol, since it has only been in effect since April 2014 and it

353. Id. at 48 .

354. Elaine E. Sutherland, Listening to the Voice of the Child: The Evolution of Participation Rights, 2013 NZ L. Rev. 335, 340 (2013).

355. Kilkelly, supra note 189, at 191.

356. Id., noting the reliance of the U.S. Supreme Court on the CRC in its opinion outlawing the juvenile death penalty, Roper v. Simmons, 543 U.S. 551 (2005), and the Canadian courts in requiring best interests of the child analysis in immigration cases. Baker v. Canada, [1999] 2 SCR 817 (Can.).

357. OP3-CRC, supra note 321. 
currently has very few signatories. ${ }^{358}$ However, the ability of individuals and groups to bring complaints directly to the Committee is a promising prospect for enforcing identity rights of individual children in the international adoption process. There are serious limitations, however. First, only those states who have signed the optional protocol can have individual complaints filed against them. ${ }^{359}$ Second, the complainants must have exhausted domestic remedies in their home countries. ${ }^{360}$ And third, the violation has to have occurred after the optional protocol entered into force ${ }^{361}$ Ameliorating this second limitation is the concept of continuing violations, where facts serving as a basis of the complaint began before the optional protocol entered into force, but continued beyond that date. ${ }^{362}$ Given the long history of secrecy in international adoption, these violations of identity rights should be readily established as continuing violations.

\section{CONCLUSION}

I adopted my first daughter from China in 2001. I was single and was convinced that domestic adoption would not be possible because birth mothers would not select me since their single status and desire for a two-parent family for their child was generally the reason they chose to place their child up for adoption. And in my heart of hearts, I really wanted to have my child as exclusively mine,

358. Id. The optional protocol has been ratified by Albania, Belgium, Bolivia, Costa Rica, Gabon, Germany, Montenegro, Portugal, Slovakia, Spain, and Thailand. G.A. Res. 66/138, art. 10, Tा 5, U.N. Doc. A/RES/66/138 (Jan. 27, 2012). See Status of Ratification Table, available at https://treaties.un.org/Pages/ ParticipationStatus.aspx (follow "CHAPTER IV" hyperlink; then follow "11.b" hyperlink). See also Gauthier de Beco, The Optional Protocol to the Convention on the Rights of the Child on a Communications Procedure: Good News?, 13 Hum. Rts. L. Rev. 367, 373-79 (2013) (discussing the content of the optional protocol).

359. OP3-CRC, supra note 321, Art. 1(3) ("No communication shall be received by the Committee if it concerns a State that is not a party to the present Protocol."); de Beco, supra note 358, at 373-79.

360. OP3-CRC, supra note 321, Art. 7(e) (providing that a communication is not admissible if domestic remedies have not been exhausted, unless "the application of the remedies is unreasonably prolonged or unlikely to bring effective relief"); de Beco, supra note 358, at 373-79.

361. OP3-CRC, supra note 321, Art. 7(g) (providing that a communication is not admissible in respect of facts that occurred before the entry into force of OP3-CRC); de Beco, supra note 358, at 373-79.

362. OP3-CRC, supra note 321, Art. 7(g) (providing that a communication is not admissible in respect of facts that occurred before the entry into force of OP3-CRC "unless those facts continued after that date."); de Beco, supra note 358, at $373-79$. 
without any birth parent involvement. I thought international adoption sounded perfect for that. Little did I know that birth parents-in their absence-would have a powerful presence in our family.

As I put my daughter to bed each night, my mind would invariably wander to her birth mother, who did not have the opportunity I had to sing her baby to sleep. By the time she was three, my daughter was making pretend phone calls to her birth mother: "Hello, birth mother! I miss you and I love you even though you couldn't adopt me." Everyone was adopted in her mind, so if she wasn't with her birth mother it was because her birth mother couldn't adopt.

When she was four (and a half?), we went back to China to adopt a younger sister for her. I carefully explained that we wouldn't be seeing her birth parents in China since we did not know who or where they were. She seemed to understand, but the minute the airplane wheels hit the tarmac, she said, "I wonder if we'll see my birth grandparents while we're here!" I hadn't thought to prepare her by saying we wouldn't be able to see ANY of her biological relatives.

By the time she was seven, she began to tell me that she thought about her birth mother every day, and we talked about her birth mother nearly every day as well. She wrote letters to her, which we burned on Mother's Days, so that the smoke would travel to China and take her good wishes to her birth mother. She wrote stories where she was reunited with her birth family (and she worked through anger issues in these stories, all of which had her idealized, fantasized birth parents do something wrong, so that they had to apologize to her and seek her forgiveness. She always gave it.).

Now, at thirteen, she still thinks about her birth mother, though perhaps not as often. She tells me when she meets a new Chinese woman-at Chinese School or in the community-she wonders if she could be her birth mother.

She would give anything to know her birth mother. And I would do anything to give her that, if only I could. It's now discomfiting how desperately I wanted to avoid her birth parents. Given the centrality of birth parents to adopted children's sense of identity, I can't avoid them. And I shouldn't.

Taking children's rights seriously, giving real meaning to the identity provisions of the CRC and the Hague Convention, requires openness in international adoption. Domestic adoption in the West has been moving toward openness for two decades. The current 
environment is ripe for removing barriers to the adopted child's right to know their birth parents in international adoption as well. 